\title{
PROTECTION OF CLIMATE DISPLACED PERSONS UNDER INTERNATIONAL LAW: A CASE STUDY FROM MATASO ISLAND, VANUATU
}

\author{
MARGaretha WeWERINKe-SingH* AND TeSs VAN GEELEN ${ }^{\dagger}$
}

\begin{abstract}
International human rights law has evolved to offer specific protection to persons who are internally displaced. This protection is becoming increasingly important as the effects of climate change are putting more populations around the world at risk of displacement. However, there is still limited empirical insight into the factors that enhance or undermine effective protection of the rights of climate displaced persons in practice. This article seeks to fill this gap, drawing on a case study of climate displacement resulting from Tropical Cyclone Pam which struck the Pacific Island nation of Vanuatu in March 2015. We note that Vanuatu has an expansive suite of laws and policies dedicated to disaster preparation, risk reduction and response, as well as climate change and disaster displacement. However, its capacity to fulfil its human rights obligations in the face of climate disasters is undermined by a lack of resources and institutional capacity. We argue that this gap must be addressed through an integrated approach to international law that emphasises human rights obligations of international cooperation and assistance along with obligations relating to climate change mitigation, adaptation and capacity building under international climate change law. Vanuatu's experience with Cyclone Pam also provides a clear case for strengthening the Warsaw International Mechanism for Loss and Damage Associated with Climate Change Impacts ('Warsaw Mechanism') in a manner that results in enhanced human rights protection for climate displaced persons.
\end{abstract}

\section{CONTENTS}

Introduction.

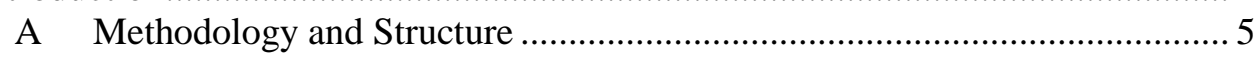

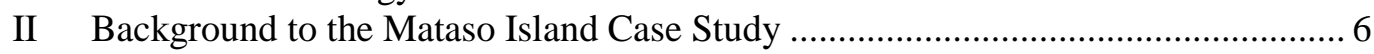

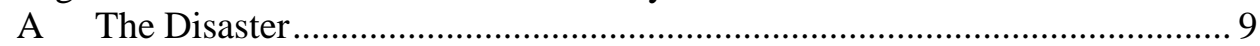

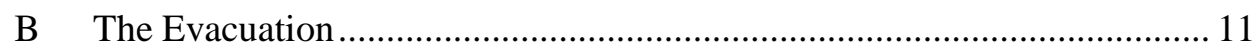

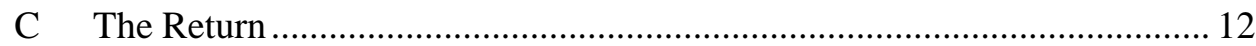

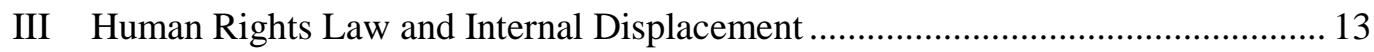

A International Framework ................................................................... 13

B Domestic Law and Policy in Vanuatu ........................................................ 15

C Protecting Human Rights in Practice: The Mataso Case Study.................. 18

IV An Integrated Approach to International Law to Protect the Rights of

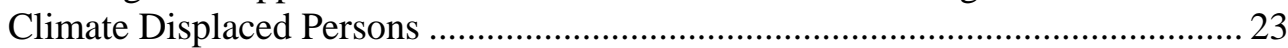

A Preventing Climate Displacement through Climate Change Mitigation .... 24

* Assistant Professor of Public International Law, Grotius Centre for International Legal Studies, Leiden University and Adjunct Senior Lecturer, Pacific Centre for Environment and Sustainable Development, University of the South Pacific.

$\dagger$ New Colombo Plan Scholar, School of Law, University of the South Pacific. This research was partially funded by the Raoul Wallenberg Institute of Human Rights and Humanitarian Law. Ethics approval was obtained from the Faculty of Arts, Law \& Education Research Committee, University of the South Pacific. The authors are indebted to Tommie Lui, Howard Lapo and Leerick Riimana for outstanding research assistance, to Richard Shing and his team at the Vanuatu Kaljoral Senta for their support throughout the project and to two anonymous referees for valuable comments. The research could not have been carried out without the participation of members of the Mataso community, the Vanuatu government and humanitarian workers who generously agreed to share their experiences and perspectives. The authors contributed equally to the work presented in this paper and, needless to say, all errors remain their own. 
B Climate Finance for Mitigation, Adaptation and Capacity Building..........26

C Remedies and Compensation for Climate Displaced Persons ..................... 32

V

Conclusion

\section{INTRODUCTION}

The phenomenon of climate displacement is complex and fraught with uncertainty. ${ }^{1}$ It is generally not possible to draw clear lines between climate change drivers and other environmental drivers, between environmental and other socio-economic drivers or between voluntary and forced cases of migration. ${ }^{2}$ This is true of both slow-onset and sudden-onset environmental threats, which themselves interact in complex ways. ${ }^{3}$ In reality, decisions to move are invariably based on a combination of these factors and there is a broad spectrum of relative 'voluntariness'. Despite these uncertainties, climate change is widely recognised as an increasingly important driver of human movement. ${ }^{4}$ The Norwegian Refugee Council's Internal Displacement Monitoring Centre reports 18.8 million new displacements by sudden-onset disasters caused by natural hazards in $2017.5^{5}$ The vast majority of those (18 million) were weatherrelated. ${ }^{6}$ These numbers do not yet account for cross-border displacement, nor do they include displacement resulting from the slow-onset adverse effects of climate change such as sea-level rise, coastal erosion, prolonged drought or changing weather patterns. ${ }^{7}$ The total number of climate displaced persons is therefore likely to be much higher, and to go up further still. The Intergovernmental Panel on Climate Change ('IPCC') predicts that the frequency and intensity of weather-related events, including storms, floods and drought, will increase as temperatures continue to rise, affecting the ability of

1 See, eg, Brendan Gogarty, 'Climate-Change Displacement: Current Legal Solutions to Future Global Problems' (2011) 21(1) Journal of Law, Information and Science 167; Frank Biermann and Ingrid Boas, 'Preparing for a Warmer World: Towards a Global Governance System to Protect Climate Refugees’ (2010) 10(1) Global Environmental Politics 60; Jane McAdam, 'Introduction' in Jane McAdam (ed), Climate Change and Displacement: Multidisciplinary Perspectives (Hart, 2010) 1, 3; Walter Kälin, Conceptualising ClimateInduced Displacement' in Jane McAdam (ed), Climate Change and Displacement: Multidisciplinary Perspectives (Hart, 2010) 81, 82.

2 See Jane McAdam (ed), Climate Change, Forced Migration, and International Law (Oxford University Press, 2012) 183; Kälin, above n 1, 81, 83-5.

3 See Jane McAdam and Marc Limon, 'Human Rights, Climate Change and Cross-Border Displacement: The Role of the International Human Rights Community in Contributing to Effective and Just Solutions' (Policy Report, Universal Rights Group, 2015) 13 ('Human Rights, Climate Change and Cross-Border Displacement').

4 United Nations Office of the High Commissioner for Human Rights, Addressing Human Rights Protection Gaps in the Context of Migration and Displacement of Persons across International Borders Resulting from the Adverse Effects of Climate Change and Supporting the Adaptation and Mitigation Plans of Developing Countries to Bridge the Protection Gaps, UN GAOR, 38 ${ }^{\text {th }}$ sess, Agenda Items 2 and 3, UN Doc A/HRC/38/21 (23 April 2018) 3 [6] ('OHCHR 2018 Report').

5 Internal Displacement Monitoring Centre, 'Global Report on Internal Displacement' (Report, Norwegian Refugee Council, May 2018) 7 <http://www.internaldisplacement.org/global-report/grid2018/> archived at <https://perma.cc/FFF7-RYLV>.

6 Ibid.

7 The precise figures for these categories of displacement are not known. 
communities around the world to live and sustain themselves. ${ }^{8}$ The risk of displacement is particularly high in developing countries with limited resources for climate change adaptation and disaster risk reduction, which are also at the forefront of climate change. ${ }^{9}$ These realities and prospects raise important questions about the capacity of international human rights law and related fields of international law to respond to the protection and assistance needs of climate displaced persons.

The role of international law in addressing climate displacement has already received considerable attention in scholarship and practice. ${ }^{10}$ Initially, much of the legal literature focused on the rights of those who were forced to cross borders as a result of climate change. Atoll island states such as Kiribati, the Maldives, the Marshall Islands and Tuvalu in particular have received much attention, as sea-level rise poses a threat to the habitability of much or all of their territory - a situation that creates an unprecedented protection gap for those at risk of losing their homeland. ${ }^{11}$ Courts and tribunals in Australia and New Zealand have already been confronted with cases where citizens from Pacific Island states have claimed refugee status on humanitarian grounds due to the impacts of climate change on their traditional lives and livelihoods. ${ }^{12}$ While none of these claims were successful, the Supreme Court of New Zealand has emphasised that its rejection of the claim should not be taken as a ruling that climate change should never create a pathway into the Refugee Convention or

8 Rajendra K Pachauri et al, 'Climate Change 2014: Synthesis Report' (Report, Intergovernmental Panel on Climate Change, 2015) 10-11, 15, 69 <https://archive.ipcc.ch/pdf/assessment-report/ar5/syr/SYR_AR5_FINAL_full_wcover.pdf > archived at <https://perma.cc/E7ZF-9WN9> ('IPCC AR5 2014').

9 Ibid 16, 73.

10 See, eg, Jane McAdam and Ben Saul, 'An Insecure Climate for Human Security? ClimateInduced Displacement and International Law' in Alice Edwards and Carla Ferstman (eds), Human Security and Non-Citizens: Law, Policy and International Affairs (Cambridge University Press, 2010) 357; Sumudu Atapattu, 'Climate Change, Human Rights, and Forced Migration: Implications for International Law' (2009) 27 Wisconsin International Law Journal 607. See also United Nations Climate Change, Submissions on Internal and Cross-Border Migration, Displacement and Other Forms of Human Mobility to the Executive Committee of the Warsaw International Mechanism on Loss and Damage Associated with Climate Change Impacts (16 May 2016) $<$ https://unfccc.int/topics/resilience/resources/submissions-on-internal-and-cross-bordermigration--displacement-and-other-forms-of-human-mobility $>$ archived at <https://perma.cc/DR8Z-JM6G〉. For stakeholder inputs to the Office of the United Nations High Commissioner for Human Rights ('OHCHR') on human rights, climate change and migration pursuant to Human Rights Council Resolution 35/20, see United Nations Human Rights Office of the High Commissioner, Human Rights, Climate Change and Migration (2018)

<https://www.ohchr.org/EN/Issues/HRAndClimateChange/Pages/HRClimateChangeAndMi gration.aspx> archived at <https://perma.cc/JFU4-XZNA>: stakeholder inputs to the OHCHR on human rights, climate change and migration pursuant to Human Rights Council Resolution 35/20.

11 See Karen Elizabeth McNamara and Chris Gibson, "WWe Do Not Want to Leave Our Land": Pacific Ambassadors at the United Nations Resist the Category of "Climate Refugees", (2009) 40 Geoforum 475, 478-9. See also Nikita Perumal, "The Place Where I Live is Where I Belong": Community Perspectives on Climate Change and Climate-Related Migration in the Pacific Island Nation of Vanuatu' (2018) 13(1) Island Studies Journal 45, 45.

12 See, eg, 0907346 [2009] RRTA 1168 (10 December 2009); AD (Tuvalu) [2014] NZIPT 501370-371 (4 June 2014); Teitiota v Chief Executive of the Ministry of Business, Innovation and Employment [2015] NZSC 107 (20 July 2015) ('Teitiota'). 
protected person jurisdiction. ${ }^{13}$ The question of how international law should evolve to become capable of offering redress for cross-border climate displacement continues to be the subject of a lively academic debate. ${ }^{14}$

In parallel, a small but growing body of scholarship has evolved around the rights of those who are displaced wholly or partly as a result of climate change within the borders of their own state. This scholarship has made important strides in situating the phenomenon of climate displacement within the wider context of international obligations of states to protect and assist internally displaced persons. ${ }^{15}$ However, there is still limited empirical insight into the extent to which, and how, the international norms that are supposed to protect those who are displaced in the context of climate change are implemented in practice. ${ }^{16}$ It is important to address this knowledge gap, not only for societal reasons but also because climate displacement is a phenomenon situated at the crossroads of different areas of international law - most notably, human rights law and climate change law - and therefore studying it can inform debates about the 'fragmentation' of international law. ${ }^{17}$ Moreover, enhanced understanding of the protection challenges related to climate displacement within a single state's territory can also inform scholarship and practice on cross-border climate displacement: both types of displacement trigger questions relating to states' capacity to protect and assist climate displaced persons and the role of international cooperation and assistance to enhance this capacity.

This article examines the role and effectiveness of human rights and climate change law based on a case study from the small island of Mataso, Vanuatu. Vanuatu is a Small Island Developing State ('SIDS') located in the Pacific Ocean, which was hit by a category five cyclone in March 2015. Vanuatu has a comprehensive and modern framework in place to address climate change and disasters. In particular, it has recently adopted a new National Climate Change and Displacement Policy, which significantly expands the protection of rights for persons displaced by climate-related disasters. ${ }^{18}$ However, as our case study reveals, Vanuatu's government faces considerable challenges in implementing these policies in order to ensure the protection of human rights in practice. Our paper situates these challenges in the context of discussions about the fragmentation of international law, discussing in particular how universal obligations derived from human rights law on the one hand and differentiated

13 Teitiota [2015] NZSC 107 (20 July 2015) 13.

14 See the material cited in AD (Tuvalu) [2014] NZIPT 501370-371 (4 June 2014).

15 See, eg, Kälin, above n 1; Stephen Castles, 'Afterword - What Now? Climate ChangeInduced Displacement after Copenhagen' in Jane McAdam (ed), Climate Change and Displacement: Multidisciplinary Perspectives (Hart, 2010) 239.

16 But see McAdam, 'Introduction', above n 1; Julie Koppel Maldonado et al, 'The Impact of Climate Change on Tribal Communities in the US: Displacement, Relocation, and Human Rights' (2013) 120 Climatic Change 601.

17 See International Law Commission, Fragmentation of International Law: Difficulties Arising from the Diversification and Expansion of International Law - Report of the Study Group of the International Law Commission, UN GAOR $58^{\text {th }}$ sess, UN Doc A/CN.4/L.682 (13 April 2006) [444].

18 Government of Vanuatu, 'National Policy on Climate Change and Disaster-Induced Displacement' (Policy, 2018) <https://www.iom.int/sites/default/files/press_release/file/iom-vanuatu-policy-climatechange-disaster-induced-displacement-2018.pdf> archived at <https://perma.cc/3R75K3JN> ('National Climate Change and Displacement Policy'). 
obligations derived from climate change law on the other can be interpreted in an integrated manner that results in enhanced protection and assistance for climate displaced persons. As such, it sheds new light on the capacity of international law to respond to one of the greatest humanitarian challenges associated with global climate change. At the same time, it provides a set of unique insights into the impact of climate displacement on affected communities and the challenges associated with ensuring adequate protection of rights for climate displaced persons in the Pacific context.

\section{A Methodology and Structure}

To shed light on the protection and assistance challenges relating to the evacuation of the Mataso community, we use a socio-legal methodology grounded in anthropology. ${ }^{19}$ This socio-legal approach is particularly suitable for addressing the under-researched 'how' and 'why' questions relating to the protection of climate displaced persons under international law. Case study selection is based, first, on the increasing evidence about the link between cyclones and climate change, ${ }^{20}$ making the Mataso evacuation a relatively clear case of climate displacement; and second, Vanuatu's comprehensive and innovative legal and policy framework relating to climate displacement, which makes the case study particularly fitting for studying questions of implementation of international safeguards. Our case study analysis draws on a range of primary sources including domestic laws and policies and semistructured interviews with community representatives, government officials and humanitarian workers, as well as reports by non-governmental organisations, government agencies and international organisations.

The article consists of two main parts. The first part examines the extent to which, and how, provisions of international human rights law relating to climate displacement are implemented at the domestic level. In this part, we first discuss Vanuatu's international obligations to respect and ensure the rights of climate displaced persons within its own territory. We proceed to analyse the domestic legal and policy framework applicable to climate displacement in Vanuatu and the extent to which this framework reflects relevant international norms. We then introduce the Mataso case study, focusing on the experiences of members of the Mataso community who were evacuated and the perspectives of local and international actors who were involved in the disaster response. We highlight gaps in human rights protection that emerge from these experiences.

The second part examines the potential of an integrated approach to international law to enhance the protection of rights of climate displaced persons. This part considers international obligations derived from both international human rights law and international climate change law relating to climate change mitigation, adaptation, capacity building and loss and damage resulting from

19 See generally Mark Goodale and Sally Engle Merry, Anthropology and Law: A Critical Introduction (New York University Press, 2017).

20 See generally Peter Stott, 'How Climate Change Affects Extreme Weather Events' (2016) 352 Science 1517-18. 
climate change. ${ }^{21}$ The Mataso case study is reintroduced to demonstrate the relationship between of each of these aspects and the protection of persons internally displaced by climate-related disasters. The case study also serves as a starting point for suggestions on how the effectiveness of the two frameworks human rights and climate change law - can be enhanced in connection with climate displacement through further integration of their components.

\section{BACKGROUND TO THE MATASO ISLAND CASE STUDY}

Vanuatu is a small island state located in the southwestern Pacific Ocean, consisting of 82 islands and with a population of around $272000 .{ }^{22}$ Roughly 75 per cent of the population live in rural villages. ${ }^{23} 15$ per cent of households have no access to improved drinking water, and 65 percent cannot access improved sanitation. ${ }^{24}$ The country's nominal Gross Domestic Product ('GDP') was estimated at US\$829 million in 2017, or US\$2949 per capita. ${ }^{25}$ The United Nations categorises Vanuatu as a Least Developed Country, in large part due its status as one of the most geophysically vulnerable countries in the world. ${ }^{26}$ From 2011 to 2015 it was ranked as the world's most vulnerable nation to natural disasters on the World Risk Index. ${ }^{27}$ Vanuatu is located in the 'Pacific Rim of Fire', experiencing moderate earthquakes almost every other day, and regular

21 See especially United Nations Framework Convention on Climate Change, opened for signature 4 June 1992, 1771 UNTS 107 (entered into force 21 March 1994) art 4 ('UNFCCC'); Paris Agreement, opened for signature 22 April 2016, [2016] ATS 24 (entered into force 4 November 2016) art 9 ('Paris Agreement'). See also Joyeeta Gupta and Karin Arts, 'Achieving the $1.5^{\circ} \mathrm{C}$ Objective: Just Implementation through a Right to (Sustainable) Development Approach' (2018) 18 International Environmental Agreements: Politics, Law and Economics 11.

22 Vanuatu National Statistics Office, '2016 Post-TC Pam Mini-Census Report' (Report, Government of Vanuatu, 21 July 2017) vol $1, \quad 1$ <https://vnso.gov.vu/index.php/component/advlisting/?view=download\&fileId=4542> archived at <https://perma.cc/78VK-K4B9> ('Post-TC Pam Mini-Census Report').

23 Secretariat of the Pacific Regional Environment Programme, 'Vanuatu National Environment Policy and Implementation Plan 2016-2030' (Report, 2017) 5 $<$ https://www.sprep.org/attachments/Publications/EMG/vanuatu-nepip.pdf> archived at $<$ https://perma.cc/8EQG-EEXS>.

24 Post-TC Pam Mini-Census Report, above n 22, 2.

25 International Monetary Fund 'World Economic Outlook Database: Vanuatu' (Report, April 2017)

<https://www.imf.org/external/pubs/ft/weo/2017/01/weodata/weorept.aspx ?sy=2010\&ey=2 $018 \&$ scsm $=1 \&$ ssd $=1 \&$ sort $=$ country \&ds $=. \& b r=1 \& p r 1 . x=26 \& p r 1 . y=10 \& c=846 \& s=$ NGDPD $\%$ 2CNGDPDPC\%2CPPPGDP\%2CPPPPC\&grp=0\&a=> archived at <https://perma.cc/4RKK-9Z37>.

26 Matthias Garschagen et al, 'World Risk Report 2015' (Report, United Nations University Institute for Environment and Human Security and Bündnis Entwicklung Hilft, 2015) 11, 46 $<$ https://collections.unu.edu/eserv/UNU:3303/WRR_2015_engl_online.pdf > archived at <https://perma.cc/A3LR-JLN3> ('World Risk Report 2015'); Department of Economic and Social Affairs, 'Vanuatu National Assessment Report: 5 Year Review of the Mauritius Strategy for Further Implementation of the Barbados Programme of Action for Sustainable $\begin{array}{llll}\text { Development' } \quad \text { (Report, } & \text { United } & \text { Nations, }\end{array}$ <https://sustainabledevelopment.un.org/content/documents/1380Vanuatu-MSI-

NAR2010.pdf> archived at <https://perma.cc/5VZK-5HXA> ('Vanuatu National Assessment Report: 5 Year Review of the Mauritius Strategy').

27 World Risk Report 2015, above n 26, 41. 
eruptions from more than a dozen active volcanoes. ${ }^{28}$ The island nation also falls within the South Pacific tropical cyclone basin ${ }^{29}$ and is subject to a high frequency of cyclones, tsunamis, storm surges, drought, flooding of both coasts and rivers, and landslides. ${ }^{30}$ The state's geographical vulnerability is exacerbated by low levels of development and low institutional capacity in a government that has only been independent since $1980 .{ }^{31}$

The population of Vanuatu is vulnerable to involuntary displacement due to both sudden-onset and slow-onset disasters, which are expected to become more prevalent in the future due to climate change. ${ }^{32}$ Vanuatu is expected to see natural disasters and extreme weather events intensify, ${ }^{33}$ and climate modelling for Vanuatu has predicted increased average temperatures and an increase in the frequency of extreme temperatures; both increased precipitation and a higher number of dry days; sea level rise; and coastal erosion. ${ }^{34}$ Vanuatu has already seen an increase in the frequency and intensity of extreme weather events due to climate change. ${ }^{35}$ As noted above, slow-onset and sudden-onset disasters can interact in complex and damaging ways, such as when flooding due to storm surges and cyclones is exacerbated by sea level rise, coastal erosion and coral reef degradation. ${ }^{36}$ While the 20 centimetre increase observed in global sea levels since the middle of the $19^{\text {th }}$ century may seem innocuous on a calm, fortified coastline, that increase spread over massive oceans means that 'there is now much more water riding on a storm surge, which makes flooding more extensive and severe' ${ }^{37}$ This effect contributed to the destructive capacity of Cyclone Pam, in addition to higher water surface temperatures which resulted in

28 Vanuatu Metrology and Geo-Hazards Department, 'Increasing Resilience to Climate Change and Natural Hazards: Environment and Social Management Framework' (World Bank Project Doc No SFG2255 REV, Government of Vanuatu, 2017) 4 <http://documents.worldbank.org/curated/en/349571468132625631/pdf/SFG2255-

REVISED-EA-P112611-Box402910B-PUBLIC-Disclosed-5-23-2017.pdf > archived at <https://perma.cc/QH5P-5XV9> ('Increasing Resilience to Climate Change and Natural Hazards').

29 Pacific Catastrophe Risk Assessment and Financing Initiative, 'Country Risk Profile: Vanuatu' (Country Profile, 2011) 3 <http://pcrafi.spc.int/documents/136> archived at <https://perma.cc/5F84-DHJC> ('PCRAFI Country Risk Profile: Vanuatu').

30 Increasing Resilience to Climate Change and Natural Hazards, above n 28, 4.

31 See generally Global Facility for Disaster Reduction and Recovery, 'Reducing the Risk of Disasters and Climate Variability in the Pacific Islands: Republic of Vanuatu Country Assessment' (Report, World Bank, 2009) <https://www.sprep.org/att/irc/ecopies/countries/vanuatu/113.pdf> archived at $<$ https://perma.cc/3DHV-2QM8>.

32 Intergovernmental Panel on Climate Change Working Group II, 'Climate Change 2007: Impacts, Adaptation and Vulnerability' (Report, Intergovernmental Panel on Climate Change, 2007) 687-716 ('IPCC AR4 2007'); IPCC AR5 2014, above n 8, 64-73.

33 Global Facility for Disaster Reduction and Recovery, Vanuatu (2017) <https://www.gfdrr.org/vanuatu> archived at <https://perma.cc/X6XP-H9ZY>; Vanuatu National Assessment Report: 5 Year Review of the Mauritius Strategy, above n 26, 6; National Climate Change and Displacement Policy, above n 18, ix.

34 Increasing Resilience to Climate Change and Natural Hazards, above n 28, 4.

35 Global Facility for Disaster Reduction and Recovery, above n 33; Vanuatu National Assessment Report: 5 Year Review of the Mauritius Strategy, above n 26, 8-9; National Climate Change and Displacement Policy, above n 18, ix.

36 Human Rights, Climate Change and Cross-Border Displacement, above n 3, 13.

37 Ibid. 
greater rainfall and higher wind speeds. ${ }^{38}$ According to the Pacific Catastrophe Risk Assessment and Financing Initiative ('PCRAFI'), Vanuatu is expected to incur, on average over the long term, losses of US\$48 million per year due to tropical cyclones and earthquakes. The PCRAFI further estimates that Vanuatu has a 50 per cent chance of experiencing a loss exceeding US\$330 million and casualties larger than 725 people from a single event in the next 50 years. ${ }^{39}$

Together, the wide range of adverse effects of climate change already put significant additional stress on environmental systems, governance structures and livelihoods in Vanuatu, which further enhances the risks of displacement across the island nation. The situation in Vanuatu illustrates how interaction between climate-related stressors on the one hand and existing socio-economic drivers of human mobility on the other can lead to a perpetual cycle of vulnerability. ${ }^{40}$ For example, it appears that more ni-Vanuatu (as the people of Vanuatu call themselves) move towards urban areas both in response to sudden-onset disasters and due to a mixture of slow-onset environmental and economic drivers. This in turn leads to continuous growth of informal settlements around the two periurban areas of Port Vila and Luganville. The expansion of informal settlements exacerbates the risk of displacement due to natural hazards, as housing and community infrastructure in these settlements tends to be fragile. Moreover, the informal settlements themselves are situated in hazard-prone areas with poor access to water and electricity. ${ }^{41}$ Where inhabitants of these informal settlements are displaced as a result of a disaster, the displacement can exacerbate their vulnerability as well as their freedom to decide whether or not to return, and if not, where else to go. ${ }^{42}$ Our case study illustrates how these dynamics affect the enjoyment of human rights in Vanuatu.

A number of cross-cutting human rights issues persist in Vanuatu. Women are marginalised in a variety of day-to-day ways, including a lack of political representation, ${ }^{43}$ cultural barriers to participation in decision-making and a prevalence of gender-based violence. ${ }^{44}$ Same-sex sexual activity is not prohibited at law in Vanuatu, but same-sex unions are not legally recognised in any form. ${ }^{45}$

38 Ibid.

39 PCRAFI Country Risk Profile: Vanuatu, above n 29, 1.

40 IPCC AR4 2007, above n 32, 693; IPCC AR5 2014, above n 8, 54, 64.

41 National Climate Change and Displacement Policy, above n 18, x.

42 OHCHR 2018 Report, UN Doc A/HRC/38/21, 6 [14].

43 There is no female representative in the country's 52-member Parliament, for example. See Pacific Women in Politics, Country Profiles: Vanuatu (United Nations Development Program, 2018) <https://www.pacwip.org/country-profiles/vanuatu/> archived at <https://perma.cc/99NP-K6NG>.

44 Bureau of Democracy, Human Rights and Labor, 'Vanuatu 2015 Human Rights Report' (Report, United States State Department, 2015) 1, 8, 10 <https://www.state.gov/documents/organization/253023.pdf> archived at $<$ https://perma.cc/7VC9-8ZX8>.

45 Vivian Gan, 'Taboo Topic, but Some See Hope for Pacific Change with Marriage "Equality" in NZ', Pacific Scoop (online), 18 August 2012 <http://pacific.scoop.co.nz/2012/08/taboo-topic-but-some-see-hope-for-pacific-change-withmarriage-equality-in-nz/> archived at <https://perma.cc/9V5E-VAHP>; Lucas Paoli Itaborahy and Jingshu Zhu, 'State-Sponsored Homophobia, a World Survey of Laws: Criminalisation, Protection and Recognition of Same-Sex Love' (Report, International Lesbian Gay Bisexual Trans and Intersex Association, May 2013) 20-1, 30 <https://www.webcitation.org/6IEmVxpKn?url=http://old.ilga.org/Statehomophobia/ILGA_ State_Sponsored_Homophobia_2013.pdf $\rangle$ archived at $\langle$ https://perma.cc/SF6C-WQCM $\rangle$. 
There is no general prohibition against discrimination based on sexual orientation or gender in Vanuatu. These issues present special risks in the context of natural disasters, and — as will be clear from our case study — require special consideration in designing and implementing disaster response activities so that existing inequalities are not inadvertently perpetuated.

\section{A The Disaster}

As noted above, our case study centres on the disaster resulting from category five Tropical Cyclone Pam which struck Vanuatu in March 2015, affecting 22 islands. The destruction and subsequent economic losses totalled approximately US\$450 million, or roughly 64 per cent of GDP. ${ }^{46}$ The Government of Vanuatu reported that 65000 people had been displaced by the disaster (roughly one quarter of the population), and some 17000 buildings were damaged or destroyed. ${ }^{47}$ Cyclone Pam was the largest ever recorded in the South Pacific, until Cyclone Winston which hit Fiji the following year. ${ }^{48}$ The small island of Mataso - home to roughly 130 people at that time - was among those most severely affected by Cyclone Pam. All buildings and most food sources on the island were destroyed, including all livestock, and people were left exposed to the elements. One man and one woman on Mataso reportedly died from injuries while waiting for medical assistance in the days that followed. ${ }^{49}$

On the afternoon before Cyclone Pam made landfall, the Mataso community was mourning the loss of a local chief, which preoccupied them to the extent that cyclone preparations were left to the last minute. In many cases, community members told us that they did not begin any preparations until just before dark that evening. ${ }^{50}$ By the middle of the night the cyclone had reached full strength, and many were forced to flee their homes as roofs were torn off. The community noted that they underestimated the severity of the threat because they were not informed about the predicted intensity of the cyclone. ${ }^{51}$ Most communities in Vanuatu are used to dealing with cyclones, which was clear from the fact that most people interviewed could not even recall the number of cyclones they had

46 Increasing Resilience to Climate Change and Natural Hazards, above n 28, 4.

47 Simone Esler, 'Vanuatu Post-Disaster Needs Assessment: Tropical Cyclone Pam' (Assessment Report, Government of Vanuatu, March 2015) ix <http://dfat.gov.au/aboutus/publications/Pages/vanuatu-post-disaster-needs-assessment-tropical-cyclone-pam-march2015.aspx> archived at 〈https://perma.cc/XY78-RNLQ>.

48 Steven P Sopko and Robert J Falvey, 'Annual Tropical Cyclone Report 2015' (Report, Joint Typhoon Warning Center, 2015) 84.

49 Jonas Cullwick, 'Mataso Receives Boat from Government', Vanuatu Daily Post (online), 29 December 2016, <http://dailypost.vu/news/mataso-receives-boat-fromgovernment/article_5462c97d-4521-5187-83fe-c70b83fcf32e.html >.

50 Interview with Interviewee 14, Mataso Island community elder, male (Mataso, Shefa Province, Vanuatu, 7 May 2018); Interview with Interviewee 18, Mataso Island community member, female, youth (Mataso, Shefa Province, Vanuatu, 7 May 2018); Interview with Interviewee 3, Mataso Island community member, father (Mataso, Shefa Province, Vanuatu, 7 May 2018).

51 Interview with Interviewee 15, Mataso Island community member, mother (Mataso, Shefa Province, Vanuatu, 7 May 2018); Interview with Interviewee 17, Mataso Island community member, female, youth (Mataso, Shefa Province, Vanuatu, 7 May 2018). 
experienced in their lives. ${ }^{52} \mathrm{~A}$ combination of this familiarity with cyclones and a lack of information contributed to the lack of awareness about the unusual intensity of Cyclone Pam.

The community was poorly equipped to prepare for the cyclone with short notice. All of the houses on the island were constructed with local materials that could not withstand Pam's record-breaking 280 kilometres per hour sustained winds. In the past, islanders in Vanuatu have prepared for serious storms by lashing down their houses to strong nearby trees, weighing down roofs with sandbags, collecting water in containers and storing it in caves or stronger buildings and storing root vegetables in underground pits where they can be preserved for weeks. ${ }^{53}$ In Mataso, caves had been used in the past to shelter from the worst storms. These traditional survival mechanisms did not appear to have been implemented in Mataso before Cyclone Pam, or only in small isolated instances because they were left to the last minute. Many community members reported taking shelter behind rocks or large trees when their homes were blown away because they did not make it to the caves in time or were not aware of them. ${ }^{54}$

No official assistance from the government, donors, international organisations or nongovernmental organisations ('NGOs') reached the island until six days after the cyclone, though one family member from the nearby capital, Port Vila, was able to visit in the days immediately following with his own fishing boat. ${ }^{55}$ Arriving the day after the cyclone, he evacuated eight people who had been injured by debris, taking them to Port Vila for medical attention. ${ }^{56}$

52 Interview with Interviewee 3, Mataso Island community member, father (Mataso, Shefa Province, Vanuatu, 7 May 2018); Interview with Interviewee 8, Mataso Island community elder, male, worked in Port Vila (Mataso, Shefa Province, Vanuatu, 7 May 2018); Interview with Interviewee 10, Mataso Island community member, mother (Mataso, Shefa Province, Vanuatu, 7 May 2018); Interview with Interviewee 13, Mataso Island community elder, male (Mataso, Shefa Province, Vanuatu, 7 May 2018); Interview with Interviewee 14, Mataso Island community elder, male (Mataso, Shefa Province, Vanuatu, 7 May 2018); Interview with Interviewee 15, Mataso Island community member, mother (Mataso, Shefa Province, Vanuatu, 7 May 2018).

53 Interview with Interviewee 3, Mataso Island community member, father (Mataso, Shefa Province, Vanuatu, 7 May 2018); Interview with Interviewee 8, Mataso Island community elder, male, worked in Port Vila (Mataso, Shefa Province, Vanuatu, 7 May 2018); Interview with Interviewee 9, Mataso Island community member, father (Mataso, Shefa Province, Vanuatu, 7 May 2018); Interview with Interviewee 10, Mataso Island community member, mother (Mataso, Shefa Province, Vanuatu, 7 May 2018).

54 Interview with Interviewee 9, Mataso Island community member, father (Mataso, Shefa Province, Vanuatu, 7 May 2018); Interview with Interviewee 10, Mataso Island community member, mother (Mataso, Shefa Province, Vanuatu, 7 May 2018); Interview with Interviewee 11, Mataso Island community member, male, youth (Mataso, Shefa Province, Vanuatu, 7 May 2018); Interview with Interviewee 12, Mataso Island community member, male, youth (Mataso, Shefa Province, Vanuatu, 7 May 2018). Interview with Interviewee 13, Mataso Island community elder, male (Mataso, Shefa Province, Vanuatu, 7 May 2018); Interview with Interviewee 14, Mataso Island community elder, male (Mataso, Shefa Province, Vanuatu, 7 May 2018); Interview with Interviewee 15, Mataso Island community member, mother (Mataso, Shefa Province, Vanuatu, 7 May 2018).

55 Interview with Interviewee 8, Mataso Island community elder, male, worked in Port Vila (Mataso, Shefa Province, Vanuatu, 7 May 2018).

56 Ibid. 
In other parts of the country, some islands did not receive any outside assistance until two weeks after the cyclone. 57

\section{B The Evacuation}

When the first government assistance reached Mataso six days after the cyclone, 63 people - almost half of the community - were evacuated to Port Vila on Efate island, located approximately 40 kilometres away, or two to three hours by powered boat. The evacuation was led by Vanuatu's National Disaster Management Office ('NDMO'), using a vessel owned by the Government of the Solomon Islands under an agreement on mutual assistance in the event of disasters between the Pacific neighbours. ${ }^{58}$ One woman was too badly injured to travel by boat, and was evacuated by helicopter one week after the cyclone for surgery in Port Vila. 59

The evacuees were mostly women, children and elderly people, leaving all uninjured men and a small number of women and children behind on the island to work on reconstruction. Community members we spoke to said that it was mutually agreed by the community that all fit men would remain on the island to rebuild homes while the women and children went to Port Vila. ${ }^{60}$ Among those evacuated was an elderly woman who had been injured, and died shortly after arriving in Port Vila, bringing Mataso's death toll to three. ${ }^{61}$ It is unclear whether she received any medical attention after arriving in Port Vila, or what caused her death.

Most evacuees spent two to three months in Port Vila. While the majority of evacuees from other islands were housed in schools and churches, most of the Mataso islanders were placed with relatives. Mataso islanders have been moving in small numbers to Port Vila since the 1980s, and have established their own neighbourhood within the city, called Ohlen Mataso. These relatives hosted the evacuees for the duration of the evacuation, in what the government calls 'host evacuation'. 62

57 Victoria Cavanagh, 'Cyclone Pam: UN Agency Reports All 22 Vanuatu Islands Reached with Relief Supplies', United Nations News (online), 27 March 2015 $<$ https://news.un.org/en/story/2015/03/494562-cyclone-pam-un-agency-reports-all-22vanuatu-islands-reached-relief-supplies> archived at <https://perma.cc/66H5-CLPZ>.

58 Interview with Interviewee 3, Mataso Island community member, father (Mataso, Shefa Province, Vanuatu, 7 May 2018); Interview with Interviewee 8, Mataso Island community elder, male, worked in Port Vila (Mataso, Shefa Province, Vanuatu, 7 May 2018); Interview with Interviewee 10, Mataso Island community member, mother (Mataso, Shefa Province, Vanuatu, 7 May 2018); Interview with Interviewee 14, Mataso Island community elder, male (Mataso, Shefa Province, Vanuatu, 7 May 2018); Interview with Interviewee 19, Senior officer at National Disaster Management Office, Port Vila (Port Vila, Shefa Province, Vanuatu, 25 July 2018).

59 Interview with Interviewee 16, Mataso Island community elder, female (Mataso, Shefa Province, Vanuatu, 7 May 2018).

60 Interview with Interviewee 3, Mataso Island community member, father (Mataso, Shefa Province, Vanuatu, 7 May 2018); Interview with Interviewee 4, Mataso Island community member, male (Mataso, Shefa Province, Vanuatu, 7 May 2018); Interview with Interviewee 6, Mataso Island community member, father, (Mataso, Shefa Province, Vanuatu, 7 May 2018); Interviewee 13; Interview with Interviewee 14, Mataso Island community elder, male (Mataso, Shefa Province, Vanuatu, 7 May 2018).

61 Cullwick, above n 49.

62 Interview with Interviewee 19, Senior officer at National Disaster Management Office, Port Vila (Port Vila, Shefa Province, Vanuatu, 25 July 2018). 


\section{The Return}

During the two months following Cyclone Pam, the NDMO sent a team to conduct safety assessments and assist those who remained on the island with rebuilding homes. ${ }^{63}$ After two months, when this team determined that it was safe to return, the NDMO provided a boat to return the Mataso islanders and provided some basic provisions that also went to the island. The International Organization for Migration ('IOM') - the UN's migration agency — was also involved in the return. An IOM staff member accompanied the returning community members and stayed on to assist with reconstruction for two to three weeks. ${ }^{64}$ At that time, most, if not all evacuees returned to Mataso island. Since then, however, several islanders have returned once more to Port Vila.

The overlap between development-related drivers of urbanisation and the factors that underpin climate displacement featured prominently in our conversations with community members in Mataso, highlighting the problem of distinguishing between 'forced' and 'voluntary' migration. At one end of the spectrum, many community members felt they had no choice but to evacuate to Port Vila, because Cyclone Pam had destroyed all shelter and food sources on the island or because they or a close relative needed medical assistance. Some women even reported being threatened with arrest if they refused to evacuate. 65

On the other hand, islanders from Mataso have been gradually relocating to Port Vila since the 1980s, due to a combination of economic and environmental factors, which are deeply interconnected on an island where there is limited cash economy and most people grow the vast majority of the goods they consume. Mataso is a small, mountainous island, consisting mainly of porous limestone rock. The area available for habitation and agriculture is very small and lowlying, with poor soil quality. While we do not have data on changes in soil quality over time, relatively frequent cyclones and tsunamis have inundated the area every few years and may have contributed to salinisation of the soil. One member of civil society with close personal and working ties to Mataso suggested that the island's limited agricultural capacity was 'the main reason' for steady migration to Port Vila, both before and after the cyclone. ${ }^{66}$ Since Cyclone Pam, much of the soil has become increasingly salinated and community members find it difficult to grow enough food. ${ }^{67}$ This appears to have contributed to an increased number of people relocating permanently to Port Vila since the cyclone, though accurate numbers could not be obtained. This movement pattern is likely to continue in future, given concerns about saltwater

63 Ibid.

64 Karina Coats, 'Vanuatu: No Ordinary Homecoming - The Mataso Community Reunited' on International Organization for Migration (27 May 2015) <http://weblog.iom.int/vanuatuno-ordinary-homecoming-\%E2\%80\%93-mataso-community-reunited $>$ archived at <https://perma.cc/6B2M-TG4M>.

65 Interview with Interviewee 15, Mataso Island community member, mother (Mataso, Shefa Province, Vanuatu, 7 May 2018).

66 Interview with Interviewee 22, Vanuatu human rights advocate and civil society leader (Port Vila, Shefa Province, Vanuatu, 6 August 2018).

67 Interview with Interviewee 6, Mataso Island community member, father, (Mataso, Shefa Province, Vanuatu, 7 May 2018); Interview with Interviewee 7, Mataso Island community member, father (Mataso, Shefa Province, Vanuatu, 7 May 2018); Interview with Interviewee 19, Senior officer at National Disaster Management Office, Port Vila (Port Vila, Shefa Province, Vanuatu, 25 July 2018). 
inundation; landslides and soil erosion; and increased vulnerability to cyclones, tsunamis, drought and sea-level rise. ${ }^{68}$ The broad spectrum of relative 'voluntariness' of climate-related mobility, as seen in the Mataso case study, underscores the need for a comprehensive human rights approach to climate change that enhances the resilience of communities, including their ability and freedom to decide about migrating or staying where they are.

\section{HumAn Rights LAW AND INTERNAL DisPlaCEMENT}

This section begins by outlining the international human rights norms that apply to displaced persons, with a focus on the Guiding Principles on Internal Displacement ('Guiding Principles'). ${ }^{69}$ It goes on to examine the extent to which these international guarantees are implemented through domestic legal and policy frameworks in Vanuatu. These laws and policies are then examined in practice by incorporating the experiences of the Mataso community members following Cyclone Pam, and comments from government officials and humanitarian workers involved in the response. In short, we find a serious divergence between the protections guaranteed on paper in Vanuatu and the experiences of community members during the disaster. This section concludes by identifying the most critical areas for improvement, while the question of enhancing the capacity of the Vanuatu government to implement policies for climate change adaptation, disaster risk reduction and the protection of human rights is the subject of Part IV, which situates the case study within the wider legal framework of international human rights law and climate change law.

\section{A International Framework}

In principle, international human rights law remains applicable during disasters and in their aftermath. ${ }^{70}$ National authorities and other actors involved in the disaster response therefore have the responsibility to ensure the human rights of all those affected by disasters are respected. ${ }^{71}$ However, some provisions of human rights treaties allow for the temporary suspension of some guarantees: the International Covenant on Civil and Political Rights ('ICCPR'), for example, allows for the derogation of some guarantees where a disaster causes a 'public emergency which threatens the life of the nation' as long as these measures do not go beyond what is 'strictly required by the exigencies of

68 Interview with Interviewee 19, Senior officer at National Disaster Management Office, Port Vila (Port Vila, Shefa Province, Vanuatu, 25 July 2018); Interview with Interviewee 22, Vanuatu human rights advocate and civil society leader (Port Vila, Shefa Province, Vanuatu, 6 August 2018).

69 United Nations Commission on Human Rights, Further Promotion and Encouragement of Human Rights and Fundamental Freedoms, Including the Question of the Programme and Methods of Work of the Commission: Human Rights and Displaced Persons - Addendum: Guiding Principles on Internal Displacement, 54 ${ }^{\text {th }}$ sess, Provisional Agenda Item 9(d), UN Doc E/CN.4/1998/53/Add.2 (11 February 1998) ('Guiding Principles').

70 See, eg, Inter-Agency Standing Committee, 'IASC Operational Guidelines on the Protection of Persons in Situations of Natural Disasters' (Report, January 2011) <https://www.ohchr.org/Documents/Issues/IDPersons/OperationalGuidelines_IDP.pdf> archived at $\langle$ https://perma.cc/T5LE-CN7U>.

71 Ibid. 
the situation' and do not constitute a prohibited form of discrimination. ${ }^{72}$ Moreover, certain guarantees such as the right to life, the prohibition of cruel, inhuman and degrading treatment, the prohibition of slavery or freedom of religion remain applicable even in times of disaster. ${ }^{73}$ The rights to health, water and sanitation, food and housing also apply at all times, and indeed require special efforts to ensure that they are respected, protected and fulfilled in the face of the additional threats posed by disasters and the recovery operations themselves. ${ }^{74}$

The Guiding Principles clarify the rights of persons affected by internal displacement due to conflict or disasters under international law. Although the Guiding Principles are as such not legally binding, they are authoritative interpretations of the human rights guarantees contained in the Charter of the United Nations, numerous human rights treaties as well as customary international law. ${ }^{75}$ Characterised as 'the key international standard on internal displacement', 76 the Guiding Principles shed light on minimum standards of assistance during displacement, as well as on the right to safe return, resettlement and reintegration. ${ }^{77}$ They define internally displaced persons or groups as those

who have been forced or obliged to flee or to leave their homes or places of habitual residence, in particular as a result of or in order to avoid the effects of armed conflict, situations of generalized violence, violations of human rights or natural or human-made disasters, and who have not crossed an internationally recognized state border. ${ }^{78}$

The Guiding Principles emphasise the importance of preventing displacement, stating explicitly that states are required to actively work to avoid displacement where possible, including by considering alternative options such as the provision of assistance in situ. ${ }^{79}$ They make clear that arbitrary

72 International Covenant on Civil and Political Rights, opened for signature 19 December 1966, 999 UNTS 171 (entered into force 23 March 1976) art 4(1) ('ICCPR'). A similar clause is contained in the European Convention for the Protection of Human Rights and Fundamental Freedoms opened for signature 4 November 1950, 213 UNTS 221, art 15 ('ECHR'). The ICESCR does not contain a derogation clause, see International Covenant on Economic, Social and Cultural Rights, opened for signature 16 December 1966, 993 UNTS 3 (entered into force 3 January 1976) ('ICESCR').

73 ICCPR art 4(2); ECHR art 15(2).

74 See Guiding Principles, UN Doc E/CN.4/1998/53/Add.2; Priyanka Bhalla et al, 'The Responsibility to Prevent and Respond to Sexual and Gender-Based Violence in Disasters and Crises' (Report, International Federation of Red Cross and Red Crescent Societies, 18 July 2018) <http://media.ifrc.org/ifrc/wp-content/uploads/sites/5/2018/07/17072018-SGBVReport_Final.pdf.pdf $>$ archived at $\langle$ https://perma.cc/5AXK-KF6D>.

75 See also Kälin, above n 1.

76 See Cecilia Jimenez-Damary, 'Foreword: The $20^{\text {th }}$ Anniversary of the Guiding Principles Building Solidarity, Forging Commitment' (2018) 59 Forced Migration Review 4.

772005 World Summit Outcome, GA Res 60/1, UN GAOR, 60 ${ }^{\text {th }}$ sess, $8^{\text {th }}$ plen mtg, Agenda Items 46 and 120, UN Doc A/RES/60/1 (24 October 2005) para 132; Mandate of the Representative of the Secretary-General on the Human Rights of Internally Displaced Persons, Human Rights Council Res 6/32, UN/HRC, $6^{\text {th }}$ sess, UN Doc A/HRC/RES/6/32 (14 December 2006) para 5; Protection of and Assistance to Internally Displaced Persons, GA Res 62/153, 62 ${ }^{\text {nd }}$ sess, Agenda Item 70(b), UN Doc A/RES/62/153 (18 December 2007) para 10; Protection of and Assistance to Internally Displaced Persons, GA Res 64/162, 64 ${ }^{\text {th }}$ sess, Agenda Item 69(b), UN Doc A/RES/64/162 (18 December 2009) para 10. See also Kälin, above $\mathrm{n} 1$.

78 Guiding Principles, UN Doc E/CN.4/1998/53/Add.2, Introduction.

79 Ibid Principles 6.3, 7.1, 7.3. 
displacement is prohibited under international human rights law, and that displacement during disasters will be considered arbitrary unless, and only for as long as, evacuation is necessary for the safety and health of those affected. ${ }^{80}$ Where circumstances permit, states must obtain free and informed consent of those affected, and must involve them in the planning and decision making process. The Guiding Principles make special note of the need to involve women in this process. ${ }^{81}$

The Guiding Principles make plain that the primary duty to provide protection and humanitarian assistance rests on the state in which displaced persons reside. ${ }^{82}$ They underscore that protection and assistance must be provided without discrimination of any kind, and that special groups such as children, women, persons with disabilities and the elderly are entitled to special protection and assistance which accounts for their specific needs. ${ }^{83}$ Where displacement does occur, the Guiding Principles stipulate that states must, 'at the minimum, regardless of the circumstances, and without discrimination' provide all internally displaced persons with safe access to essential food and potable water, adequate shelter, appropriate clothing, and essential medical services and sanitation. ${ }^{84}$ The right to education must be protected during displacement, and special efforts must be made to include women and girls. ${ }^{85}$ Finally, the Guiding Principles set out the obligations of state authorities to establish the conditions for safe return or resettlement, and to facilitate this process in a way that is dignified and voluntary. ${ }^{86}$ The following parts consider the implementation of these international safeguards in domestic law, policy and practice in Vanuatu.

\section{B Domestic Law and Policy in Vanuatu}

Vanuatu is a republic and multi-party parliamentary democracy with a hybrid legal system. Pre-independence British and French statutes, English common law and indigenous custom are all recognised as formal sources of law. ${ }^{87}$ Vanuatu's Constitution enshrines a range of civil and political human rights, including the right to life, the right to freedom of movement and freedom from unjust deprivation of property. ${ }^{88}$ Vanuatu has ratified the ICCPR; $; 9$ the Convention on Elimination of All Forms of Discrimination against Women, including the optional Protocol; 90 the Convention on the Rights of the Child, including the Optional Protocols on the Involvement of Children in Armed Conflict and on the

80 Ibid Principles 6.2(d), 6.3.

81 Ibid Principles 6.2(d), 6.3, 7.1, 7.3, 8, 9.

82 Ibid Principle 25.

83 Ibid Principle 4.2.

84 Ibid Principles 18, 19.

85 Ibid Principle 23.

86 Ibid Principle 28.

87 See generally David Weisbrot, 'Custom, Pluralism, and Realism in Vanuatu: Legal Development and the Role of Customary Law' (1989) 13(1) Pacific Studies 65.

88 Constitution of the Republic of Vanuatu art 5(1).

89 ICCPR.

90 Convention on the Elimination of All Forms of Discrimination against Women, opened for signature 18 December 1979, 1249 UNTS 13 (entered into force 3 September 1981); Optional Protocol to the Convention on the Elimination of All Forms of Discrimination against Women, opened for signature on 6 October 1999, 2131 UNTS 83 (entered into force 22 December 2000). 
Sale of Children, Child Prostitution and Child Pornography; ${ }^{91}$ and the Convention on the Rights of Persons with Disabilities.92 Although it has not ratified the International Covenant on Economic, Social and Cultural Rights, the norms contained in this treaty are arguably binding on it as customary international law. ${ }^{93}$ Vanuatu has also ratified the United Nations Framework Convention on Climate Change ('UNFCCC'), 94 the Kyoto Protocol to the United Nations Framework Convention on Climate Change ('Kyoto Protocol') $)^{95}$ and the Paris Agreement, ${ }^{96}$ and submitted its first Nationally Determined Contribution ('NDC') under the latter in 2016.97

As one of the world's most vulnerable countries to natural disasters, and already finding itself on the front line against some of the most severe consequences of global warming, it is perhaps not surprising that Vanuatu has a relatively expansive suite of laws and policies dedicated to disaster preparation, risk reduction and response, as well as climate change and disaster displacement. Indeed, many of Vanuatu's laws and policies on climate change adaptation and disaster risk reduction were the first of their kind in the Pacific region. ${ }^{98}$ National disaster preparedness and response in Vanuatu is coordinated by the NDMO, which is overseen by the Ministry of Climate Change and Adaptation. Vanuatu is one of only a handful of countries to have a dedicated climate change ministry, which was established in 2014 with support from the German Development Agency, GIZ. ${ }^{99}$

91 Convention on the Rights of the Child, opened for signature 20 November 1989, 1577 UNTS 3 (entered into force 2 September 1990); Optional Protocol to the Convention on the Rights of the Child on the Involvement of Children in Armed Conflict, opened for signature 19 December 2011, 2173 UNTS 222 (entered into force 12 February 2002); Optional Protocol to the Convention on the Rights of the Child on the Sale of Children, Child Prostitution and Child Pornography, opened for signature 25 May 2000, 2171 UNTS 227 (entered into force 18 January 2002).

92 Convention on the Rights of Persons with Disabilities, opened for signature 13 December 2006, 2515 UNTS 3 (entered into force 3 May 2008).

93 See Olivier de Schutter et al, 'Commentary to the Maastricht Principles on Extraterritorial Obligations of States in the Area of Economic, Social and Cultural Rights' (2012) 34 Human Rights Quarterly 1084, 1121. See also, Eleanor D Kinney, 'The International Human Right to Health: What Does this Mean for Our Nation and the World?' (2001) 34 Indiana Law Review 1457, 1467.

94 UNFCCC.

95 Kyoto Protocol to the United Nations Framework Convention on Climate Change, opened for signature 16 March 1998, 2303 UNTS 148 (entered into force 16 February 2005) ('Kyoto Protocol').

96 Paris Agreement.

97 Republic of Vanuatu, 'Intended Nationally Determined Contribution (INDC)', Submission to the United Nations Framework Convention on Climate Change, 2015, <http://www4.unfccc.int/ndcregistry/PublishedDocuments/Vanuatu\%20First/VANUATU\% 20\%20INDC\%20UNFCCC\%20Submission.pdf> archived at <https://perma.cc/2QVZYJAC>.

98 Global Facility for Disaster Reduction and Recovery, above n 33. See Republic of Vanuatu, 'Disaster Risk Reduction and Disaster Management National Action Plan (2006-2016)' (Project Report No 83, Pacific Islands Applied Geoscience Commission, May 2007) 4; National Advisory Committee on Climate Change, 'Republic of Vanuatu: National Adaptation Programme for Action (NAPA)’ (Policy, Government of Vanuatu, December 2007); Government of Republic of Vanuatu, 'Vanuatu Climate Change and Disaster Risk Reduction Policy 2016-2030' (Project Report, Government of Vanuatu, 2015).

99 Deutsche Gesellschaft für Internationale Zusammenarbeit GmbH, known as GIZ, the German development agency. 
Vanuatu's new National Climate Change and Displacement Policy is one of the world's most progressive policies on climate-driven displacement. ${ }^{100}$ Developed with assistance from IOM, it is ambitious in scope, and comprehensively operationalises Vanuatu's international obligations to protect the human rights of those displaced by disasters and climate change. At a consultation session with key stakeholders in 2017, IOM's Chief of Mission Dr Lesikimakuata Korovavala noted that 'Vanuatu is among the first countries in the world to prepare such a policy and is venturing into new territory with this initiative'. ${ }^{101}$ Developed largely in response to the protection gaps that emerged during Cyclone Pam (highlighted below), the new policy adopts the term 'disaster' rather than 'natural disaster' to acknowledge that vulnerability is dependent on social factors as much as geophysical hazards. ${ }^{102}$ As the policy notes:

Population growth, weak governance structures, environmental degradation and poor urban planning are also important factors that weaken resilience and increase the effects of climate change, exposing people to increased risks of displacement. 103

The policy reflects many key rights protected in the Guiding Principles, including the right to safe return, resettlement and reintegration; ${ }^{104}$ special protection and assistance for vulnerable groups; 105 free and informed consent, including the involvement of women in decision making; 106 liberty, dignity and security during displacement and recovery; ${ }^{107}$ non-discrimination in the provision of food, water, sanitation, medical attention and shelter; 108 and education. ${ }^{109}$ It also addresses gender responsiveness, community participation and climate change adaptation as crosscutting issues. ${ }^{110}$ However, concerns remain regarding the capacity of the Vanuatu government to implement the policy, as discussed in more detail in the following parts.

100 National Climate Change and Displacement Policy, above n 18. See also Fern Napwatt, 'Vanuatu Prepares Its Population Displacement Policy', Vanuatu Daily Post (online), 1 July $2017<$ http://dailypost.vu/news/vanuatu-prepares-its-population-displacementpolicy/article_df1f6d0d-4c50-5ff8-82ba-f3f92c776e17.html>.

101 Napwatt, above n 100.

102 National Climate Change and Displacement Policy, above n 18, VI.

103 Ibid VII, quoting Nansen Initiative, 'Agenda for the Protection of Cross-Border Displaced Persons in the Context of Disasters and Climate Change' (Agenda, Nansen Initiative, December 2015) vol $1, \quad 6 \quad<$ https://nanseninitiative.org/wpcontent/uploads/2015/02/PROTECTION-AGENDA-VOLUME-1.pdf> ('Agenda for the Protection of Cross-Border Displaced Persons').

104 Guiding Principles, UN Doc E/CN.4/1998/53/Add.2, Principle 28; National Climate Change and Displacement Policy, above n 18, 18, 26-7, 29, 32, 37, 42.

105 Guiding Principles, UN Doc E/CN.4/1998/53/Add.2, Principle 4.2; National Climate Change and Displacement Policy, above n 18, 10, 18-19, 22, 26.

106 Guiding Principles, UN Doc E/CN.4/1998/53/Add.2, Principle 7.3; National Climate Change and Displacement Policy, above n 18, 17, 18, 26-7.

107 Guiding Principles, UN Doc E/CN.4/1998/53/Add.2, Principle 8, 9; National Climate Change and Displacement Policy, above n 18, 17, 18, 27, 32-3.

108 Guiding Principles, UN Doc E/CN.4/1998/53/Add.2, Principle 18, 19; National Climate Change and Displacement Policy, above n 18, 17, 26, 32, 46.

109 Guiding Principles, UN Doc E/CN.4/1998/53/Add.2, Principle 23; National Climate Change and Displacement Policy, above n 18, 18, 26, 39, 42.

110 National Climate Change and Displacement Policy, above n 18, 8, 17, 19. 


\section{Protecting Human Rights in Practice: The Mataso Case Study}

Despite Vanuatu's express commitment to human rights principles and standards, various human rights issues emerged during and after Cyclone Pam. Shortly after the cyclone hit, a group of UN experts on housing, internal displacement, and rights of elderly people and people with disabilities called on Vanuatu to ensure the protection of rights during the disaster recovery. ${ }^{111}$ Our conversations with Mataso island community members, civil society and government officers suggest that human rights protection was undermined by a lack of preparation and institutional capacity within the government and a serious lack of funding. ${ }^{12}$ As noted above, there was no assistance to the Mataso community until six days after the disaster. Two people reportedly died from injuries while waiting for evacuation to Port Vila, and an elderly woman passed away shortly after arriving in Port Vila. While they waited for assistance, the community members had no adequate shelter and little food or water, as every home and garden had been destroyed, every animal was killed and most water sources were polluted with salt water and debris. ${ }^{113}$ The overall situation undermined the enjoyment of a range of human rights, including the rights to life, health, housing, food, water, sanitation and education.

The evacuation also raised a number of human rights issues. Although the government claims that the relocation was voluntary, many of the evacuees reported having 'no choice', and some female community members reported being threatened with arrest if they would not agree to evacuate and cooperate in the evacuation. ${ }^{114}$ In this regard, the Mataso case study serves as a reminder that unless movement is undertaken in a voluntary and planned way with dignity and support, it will invariably be a costly, traumatic and often dangerous experience, best viewed as a matter of last resort. ${ }^{115}$ Members of civil society also expressed serious concern about the widespread failure to consult women or vulnerable

111 The group included Leilani Farha, Special Rapporteur on Adequate Housing; Chaloka Beyani, Special Rapporteur on the Human Rights of Internally Displaced Persons; Catalina Devandas-Aguilar, Special Rapporteur on the Rights of Persons with Disabilities; and Rosa Kornfeld-Matte, the Independent Expert on the Enjoyment of All Human Rights by Older Persons: Office of the High Commissioner for Human Rights, 'Vanuatu: After Devastation, UN Experts Call to Protect Human Rights of All in Disaster Response' (Press Release, 15 March

$<$ https://www.ohchr.org/EN/NewsEvents/Pages/DisplayNews.aspx?NewsID=15739\&LangI $\mathrm{D}=\mathrm{E}>$.

112 Interview with Interviewee 19, Senior officer at National Disaster Management Office, Port Vila (Port Vila, Shefa Province, Vanuatu, 25 July 2018); Interview with Interviewee 20, Policymaker at GIZ, Vanuatu (Port Vila, Shefa Province, Vanuatu, 20 July 2018).

113 Interview with Interviewee 15, Mataso Island community member, mother (Mataso, Shefa Province, Vanuatu, 7 May 2018); Interview with Interviewee 16, Mataso Island community elder, female (Mataso, Shefa Province, Vanuatu, 7 May 2018); Interview with Interviewee 14, Mataso Island community elder, male (Mataso, Shefa Province, Vanuatu, 7 May 2018); Interview with Interviewee 13, Mataso Island community elder, male (Mataso, Shefa Province, Vanuatu, 7 May 2018).

114 Interview with Interviewee 15, Mataso Island community member, mother (Mataso, Shefa Province, Vanuatu, 7 May 2018).

115 See $O H C H R 2018$ Report, UN Doc A/HRC/38/21, 12 [47]. 
groups about evacuation procedures. ${ }^{116}$ While the Guiding Principles imply an exception to states' obligation to consult those affected before evacuating them where emergency circumstances pose an urgent threat to health and safety, there were no such circumstances in Mataso as the cyclone had already passed. No imminent natural hazards or health threats remained to prevent the authorities from consulting the community prior to evacuating.

The importance of consultation is also apparent when considering the obligation of duty bearers to proactively work to avoid displacement by considering alternative options, as stipulated in the Guiding Principles. Our fieldwork suggests that in situ assistance to the Mataso community might have been preferable to evacuation in the circumstances, yet it does not seem to have been considered or discussed with the community. Certainly, those requiring urgent medical attention needed to be evacuated to the hospital in Port Vila, as there are no medical facilities in Mataso. However, some community members who were neither ill nor injured noted that they would have preferred to stay on Mataso so that they could have started to rebuild their homes and replant their gardens immediately after the cyclone. ${ }^{117}$ When they returned from Port Vila three months later, they found that the gardens were overgrown and that plants buried under landslides had perished and could not be recovered. It is conceivable that more community members could have remained safely on Mataso if they had been provided with temporary shelter while they rebuilt their homes, and some basic food, water and other household necessities. Members of civil society that we spoke with noted that if emergency shelter is required because homes have been destroyed, it would be preferable to provide that shelter within or close to the community, so that evacuees can return easily and cheaply to their homes each day to begin rebuilding immediately, returning to the emergency shelter in the evening to sleep. ${ }^{118}$

The evacuation particularly undermined the rights of elderly people and people with disabilities. We spoke about this with officials at the NDMO, which coordinated the evacuation, who highlighted a number challenges the NDMO faced in carrying out the evacuation operations. In particular, they noted that the evacuation was rushed because of communication and coordination challenges due to a lack of staff and resources. ${ }^{119}$ A lack of specialised equipment made it difficult and dangerous to transport people with disabilities, especially the elderly, in boats from Mataso to Port Vila. People had to be carried onto boats by family members and received no special treatment. ${ }^{120}$ This lack of special

116 Interview with Interviewee 27, Officer at Oxfam Vanuatu (Port Vila, Shefa Province, Vanuatu, 21 August 2018); Interview with Interviewee 28, Officer at International Organization for Migration in Vanuatu (Port Vila, Shefa Province, Vanuatu, 21 August 2018).

117 Interview with Interviewee 15, Mataso Island community member, mother (Mataso, Shefa Province, Vanuatu, 7 May 2018).

118 Interview with Interviewee 22, Vanuatu human rights advocate and civil society leader (Port Vila, Shefa Province, Vanuatu, 6 August 2018); Interview with Interviewee 23, Officer at International Organization for Migration, Vanuatu (Port Vila, Shefa Province, Vanuatu, 8 August 2018).

119 Interview with Interviewee 19, Senior officer at National Disaster Management Office, Port Vila (Port Vila, Shefa Province, Vanuatu, 25 July 2018).

120 Interview with Interviewee 15, Mataso Island community member, mother (Mataso, Shefa Province, Vanuatu, 7 May 2018). 
treatment appears in contrast with the principle of non-discrimination which, as clarified in the Guiding Principles, requires affirmative measures in the context of displacement. ${ }^{121}$

When the Mataso evacuees arrived in Port Vila, the NDMO had not yet set up evacuation centres, and there was a shortage of appropriate public buildings that could be used to house evacuees (especially because many had been damaged by the cyclone). Some community members were placed in schools and churches, but no management or support services were allocated to these centres for several days, in most cases. ${ }^{122}$ Few of these buildings were equipped with disabled access or facilities, and the absence of provisions or medical services in the first days forced evacuees to fend for themselves. ${ }^{123}$ In part because the schools were being used as evacuation centres, none of the evacuated children attended school in the months following the cyclone, along with many children who were not evacuated, disrupting the enjoyment of their right to education. ${ }^{124}$

As noted earlier, Cyclone Pam is widely considered to be the worst natural disaster to have ever affected Vanuatu. It was also the first instance in which the NDMO had been required to establish central evacuation centres since the department was established in 2000. ${ }^{125}$ It had no guidelines on establishing or operating evacuation centres, and still has none - an issue that was highlighted as a priority area for future capacity building by officials at the NDMO and within the humanitarian sector. ${ }^{126}$ They noted that without guidelines for identifying appropriate facilities, provision of food and water, spacing of bedding, and supply of equipment and support staff for people with disabilities, it was extremely difficult to 'make sure that people were taken care of'.127 Members of civil society also underscored that the government still needs to

121 Guiding Principles, UN Doc E/CN.4/1998/53/Add.2, Principle 4.2.

122 Interview with Interviewee 19, Senior officer at National Disaster Management Office, Port Vila (Port Vila, Shefa Province, Vanuatu, 25 July 2018).

123 Interview with Interviewee 2, Mataso Island community member, mother (Mataso, Shefa Province, Vanuatu, 7 May 2018); Interview with Interviewee 10, Mataso Island community member, mother (Mataso, Shefa Province, Vanuatu, 7 May 2018).

124 Guiding Principles, UN Doc E/CN.4/1998/53/Add.2, Principle 23; Interview with Interviewee 2, Mataso Island community member, mother (Mataso, Shefa Province, Vanuatu, 7 May 2018); Interview with Interviewee 8, Mataso Island community elder, male, worked in Port Vila (Mataso, Shefa Province, Vanuatu, 7 May 2018); Interview with Interviewee 14, Mataso Island community elder, male (Mataso, Shefa Province, Vanuatu, 7 May 2018); Interview with Interviewee 15, Mataso Island community member, mother (Mataso, Shefa Province, Vanuatu, 7 May 2018); Interview with Interviewee 17, Mataso Island community member, female, youth (Mataso, Shefa Province, Vanuatu, 7 May 2018); Interviewee 30, UNICEF officer in Vanuatu, (Port Vila, Shefa Province, Vanuatu, 24 August 2018); Interview with Interviewee 28, Officer at International Organization for Migration in Vanuatu (Port Vila, Shefa Province, Vanuatu, 21 August 2018). See also Committee on the Rights of the Child, General Comment No 1, Article 29(1): The Aims of Education, UN Doc CRC/GC/2001/1 (17 April 2001) annex IX.

125 Pacific Community, Tropical Cyclone Pam: Lessons Learned Workshop Report (Report, June 2015) $20 \quad<$ https://www.spc.int/sites/default/files/wordpresscontent/wpcontent/uploads/2016/12/TC-Pam-Lessons-Learned-Report.pdf> ('TC Pam Lessons Learned Report').

126 Interview with Interviewee 19, Senior officer at National Disaster Management Office, Port Vila (Port Vila, Shefa Province, Vanuatu, 25 July 2018); Interviewee 30, UNICEF officer in Vanuatu, (Port Vila, Shefa Province, Vanuatu, 24 August 2018).

127 Interview with Interviewee 19, Senior officer at National Disaster Management Office, Port Vila (Port Vila, Shefa Province, Vanuatu, 25 July 2018). 
develop clear guidelines on the protection of women, children, the elderly, people with disabilities and LGBTI individuals, including the provision of appropriate and safe facilities. ${ }^{128}$ They further noted that during the evacuations, there was no identification or systematic management of communicable diseases such as tuberculosis or HIV among the evacuee populations, or consideration of how improper facilities could accelerate the spread of disease, with implications for the enjoyment of the right to health. ${ }^{129}$

The lack of management and improper facilities at the centres also increased the risk of gender-based violence or sexual assault. ${ }^{130}$ While this was not an issue we were able to investigate directly in our study due to the sensitivity of sexual violence issues, evacuees described the centres as 'too crowded', 'bad' and 'not suitable'. ${ }^{131}$ One man that we spoke to had remained on Mataso while his mother was evacuated to a centre in Port Vila. He told us that the conditions were so unsuitable for elderly people that after a week there his cousins in Port Vila collected her from the centre and hosted her for the rest of the period. ${ }^{132} \mathrm{~A}$ member of civil society noted that even if their homes are unsafe, people always prefer to go home than stay in the centres if they can. ${ }^{133}$ They further noted that only the most vulnerable community members, such as the disabled and elderly, tended to remain in the centres, because they had no choice. ${ }^{134}$

A human rights advocate in Port Vila also noted that LGBTI individuals faced a heightened risk of discrimination and violence during displacement in Vanuatu because they are generally not recognised as a marginalised or vulnerable group by the government, resulting in a complete lack of affirmative protection measures as required under human rights law.135 Another member of civil society also discussed this gap, but noted that 'small steps' are being made in the right direction, largely due to pressure from donors and NGOs. ${ }^{136}$ Another pointed out that the gender and protection cluster for disaster response in

128 Interview with Interviewee 23, Officer at International Organization for Migration, Vanuatu (Port Vila, Shefa Province, Vanuatu, 8 August 2018); Interview with Interviewee 26, Senior Officer at Oxfam Vanuatu (Port Vila, Shefa Province, Vanuatu, 20 August 2018); Interviewee 30, UNICEF officer in Vanuatu, (Port Vila, Shefa Province, Vanuatu, 24 August 2018).

129 Interview with Interviewee 22, Vanuatu human rights advocate and civil society leader (Port Vila, Shefa Province, Vanuatu, 6 August 2018); Interview with Interviewee 23, Officer at International Organization for Migration, Vanuatu (Port Vila, Shefa Province, Vanuatu, 8 August 2018).

130 TC Pam Lessons Learned Report, above n 125, 20.

131 Interview with Interviewee 2, Mataso Island community member, mother (Mataso, Shefa Province, Vanuatu, 7 May 2018); Interview with Interviewee 4, Mataso Island community member, male (Mataso, Shefa Province, Vanuatu, 7 May 2018).

132 Interview with Interviewee 4, Mataso Island community member, male (Mataso, Shefa Province, Vanuatu, 7 May 2018).

133 Interview with Interviewee 26, Senior Officer at Oxfam Vanuatu (Port Vila, Shefa Province, Vanuatu, 20 August 2018).

134 Ibid.

135 Interview with Interviewee 22, Vanuatu human rights advocate and civil society leader (Port Vila, Shefa Province, Vanuatu, 6 August 2018); Guiding Principles, UN Doc E/CN.4/1998/53/Add.2 4.2, 7.3; Committee on the Elimination of Discrimination against Women, General Recommendation No 37 on Gender-related Dimensions of Disaster Risk Reduction in the Context of Climate Change, UN Doc CEDAW/C/GC/37 (7 February 2018).

136 Interview with Interviewee 26, Senior Officer at Oxfam Vanuatu (Port Vila, Shefa Province, Vanuatu, 20 August 2018). 
Vanuatu is the only cluster which still does not have a permanent, dedicated coordinator within the government, which, they argued, undermined effective long-term planning on issues related to gender and vulnerable groups. ${ }^{137}$ At the time, there were no domestic legal protections for vulnerable groups, whether in disasters or generally. However, the new National Climate Change and Displacement Policy does include a wide range of affirmative protections for such groups, which create new standards of protection in future disasters. For example, one of the guiding principles of the policy is '[g]ender equity and responsiveness', which requires that planning for durable solutions to displacement and disasters 'must be responsive to the different risks and needs of all people, including women, men, children and LGBTQI people' and that each of these groups must have 'equal opportunities to lead community-driven recovery processes'. 138

Many of the evacuees from Mataso were placed with extended family living in Port Vila, rather than in the central evacuation centres. In our study, these evacuees reported feeling discomfort about the additional burden their presence posed on their relatives, many of whom were themselves affected by the cyclone and subsequent flooding. ${ }^{139}$ Officials from the NDMO told us that because evacuation centres had not been set up yet when the Mataso evacuees arrived, and because the Office was spread so thin with some 65000 people displaced by the cyclone, they decided to place the Mataso islanders with their relatives in Port Vila because it was the 'cheapest and fastest solution', and freed the government to focus on providing basic supplies like food and water, and coordinating the evacuation centres for other communities. ${ }^{140}$

The Mataso islanders disagree with the government officials we spoke to about the quantity of provisions that were provided during the time they spent in Port Vila. While government officials claimed they provided enough basic foodstuffs to survive on for the duration, ${ }^{141}$ most evacuees claim they only received a few days' worth of biscuits and water from the government, and that the rest of the time they survived on gifts from friends and family in Port Vila, or from humanitarian organisations. ${ }^{142}$ It is not disputed that no substantial support was provided for long-term recovery. As one Mataso woman put it, 'we come in

137 Interviewee 29, UN officer in Vanuatu (Port Vila, Shefa Province, Vanuatu, 23 August 2018).

138 National Climate Change and Displacement Policy, above n 18, 2.

139 Interview with Interviewee 9, Mataso Island community member, father (Mataso, Shefa Province, Vanuatu, 7 May 2018); Interview with Interviewee 14, Mataso Island community elder, male (Mataso, Shefa Province, Vanuatu, 7 May 2018); Interviewee 15.

140 Interview with Interviewee 19, Senior officer at National Disaster Management Office, Port Vila (Port Vila, Shefa Province, Vanuatu, 25 July 2018).

141 Interview with Interviewee 19, Senior officer at National Disaster Management Office, Port Vila (Port Vila, Shefa Province, Vanuatu, 25 July 2018).

142 Interview with Interviewee 1, Mataso Island community member, father (Mataso, Shefa Province, Vanuatu, 7 May 2018); Interview with Interviewee 2, Mataso Island community member, mother (Mataso, Shefa Province, Vanuatu, 7 May 2018); Interview with Interviewee 6, Mataso Island community member, father, (Mataso, Shefa Province, Vanuatu, 7 May 2018); Interview with Interviewee 10, Mataso Island community member, mother (Mataso, Shefa Province, Vanuatu, 7 May 2018). See also TC Pam Lessons Learned Report, above n 125, 20: the report also noted that some of the centres 'initially received no supplies because they were not registered or recorded'. 
empty to Vila and go back empty to Mataso'. ${ }^{143}$ Based on our interviews, it seems that a local Member of Parliament who was from Mataso himself - Kalo Seule - provided the vast majority of assistance to the Mataso community, rather than the NDMO or other government agencies. ${ }^{144}$

While the government has undertaken or participated in a number of studies since Cyclone Pam to identify and address these issues and to inform new policies, ${ }^{145}$ both government officials and members of civil society raised serious concerns about the capacity of the government to implement these new policies. ${ }^{146}$ This lack of capacity on the part of the government is the subject of the following part, which places the case study in a wider context of international obligations to prevent climate displacement by acting to reduce greenhouse gas emissions. In addition, we consider international obligations to protect the rights of displaced persons through the provision of finance for mitigation, adaptation, capacity building and addressing loss and damage in developing states such as Vanuatu.

\section{AN INTEGRATED APPROACH TO INTERNATIONAL LAW TO PROTECT THE RightS OF CLIMATE DisPlaCED PERSONS}

In places like Mataso, no action by the Vanuatu government could entirely prevent the violation of rights if anthropogenic climate change is not mitigated by reducing global emissions. Where land that is fundamental to indigenous or cultural ways of life becomes uninhabitable and relocation is the only option, even dignified, planned, and supported migration will still result in a violation of

143 Interview with Interviewee 2, Mataso Island community member, mother (Mataso, Shefa Province, Vanuatu, 7 May 2018).

144 Interview with Interviewee 8, Mataso Island community elder, male, worked in Port Vila (Mataso, Shefa Province, Vanuatu, 7 May 2018); Interview with Interviewee 14, Mataso Island community elder, male (Mataso, Shefa Province, Vanuatu, 7 May 2018).

145 See TC Pam Lessons Learned Report, above n 125.

146 Interview with Interviewee 19, Senior officer at National Disaster Management Office, Port Vila (Port Vila, Shefa Province, Vanuatu, 25 July 2018); Interview with Interviewee 20, Policymaker at GIZ, Vanuatu (Port Vila, Shefa Province, Vanuatu, 20 July 2018); Interview with Interviewee 22, Vanuatu human rights advocate and civil society leader (Port Vila, Shefa Province, Vanuatu, 6 August 2018); Interview with Interviewee 23, Officer at International Organization for Migration, Vanuatu (Port Vila, Shefa Province, Vanuatu, 8 August 2018). 
the rights to land, culture and self-determination. ${ }^{147}$ This risk was already foreseen 20 years ago when the Guiding Principles affirmed that states had a particular duty to protect against the displacement of indigenous peoples, minorities, peasants, pastoralists and other groups with a special dependency and attachment to their lands'. ${ }^{148}$ It is therefore important to consider the wider context of states' obligations to address climate change and its adverse effects under international law.

The Paris Agreement confirmed that obligations under climate change law on the one hand and human rights law on the other need to be complied with in an integrated manner. ${ }^{149}$ The following parts describe what this could mean in practice in relation to the prevention of climate displacement and the protection of the rights of climate displaced persons.

\section{A Preventing Climate Displacement through Climate Change Mitigation}

At the 1992 UN Earth Summit in Rio de Janeiro, states adopted the UNFCCC with the ultimate objective of stabilising the climate 'at a level that would prevent dangerous anthropogenic interference with the climate system' and in a time frame 'sufficient to allow ecosystems to adapt naturally to climate change, to ensure that food production is not threatened and to enable economic development to proceed in a sustainable manner'. ${ }^{150}$ States' commitments to achieve this objective are based on the principle of common but differentiated responsibilities and respective capabilities ('CBDRRC'), with different

147 See United Nations Declaration on the Rights of Indigenous Peoples, GA Res 61/295, UN GAOR, $61^{\text {st }}$ sess, $107^{\text {th }}$ plen mtg, Agenda Item 68, Supp No 49, UNGA A/RES/61/295 (2 October 2007, adopted 13 September 2007) annex ('UNDRIP') arts 3 (self-determination and economic, social and cultural development), 8 (creating a duty of States to 'provide effective mechanisms for prevention of, and redress for' any action which has the effect of 'dispossessing them of their lands, territories or resources'), 11 (the right to practise cultural traditions and customs, including the preservation and maintenance of historical sites), 26 (guaranteeing the right to 'the lands, territories and resources which they have traditionally owned, occupied or otherwise used or acquired'), 28 (guaranteeing a right to just, fair and equitable compensation for lands that have been damaged without free, prior and informed consent), 29 (guaranteeing the 'right to the conservation and protection of the environment and the productive capacity of their lands or territories and resources'). See generally Cosmin Corendea, 'Development Implications of Climate Change and Migration in the Pacific' (Working Paper No 3/2016, Centre for International Sustainable Development Law, McGill University, Montreal, 2016); Olivia Serdeczny, Eleanor Waters and Sander Chan, 'Non-Economic Loss and Damage in the Context of Climate Change: Understanding the Challenges' (Discussion Paper No 3/2016, Deutsches Institut für Entwicklungspolitik, 2016). See also P Brian Fisher, 'Climate Change and Human Security in Tuvalu' (2011) 23 Global Change, Peace and Security 293; Nansen Initiative, 'Human Mobility, Natural Disasters and Climate Change in the Pacific: Outcome Report from Nansen Initiative on Disaster-Induced Cross-Border Displacement Pacific Regional Consultation' (Outcome Report, Nansen Initiative, 2013); Adelle Thomas and Lisa Benjamin, 'Policies and Mechanisms to Address Climate-Induced Migration and Displacement in Pacific and Caribbean Small Island Developing States' (2018) 10 International Journal of Climate Change Strategies and Management 86.

148 Guiding Principles, UN Doc E/CN.4/1998/53/Add.2, Principles 8, 9.

149 Paris Agreement 11.

150 UNFCCC art 2. 
obligations for developed versus developing states. ${ }^{151}$ The individual quantified emission reduction targets subsequently set for developed states under the Kyoto Protocol were unambitious, and yet most of the states that were bound by these targets failed to meet them. ${ }^{152}$ Many states, including Australia, Canada and New Zealand, actually substantially increased their emissions during the first commitment period, and others like the United Kingdom only managed to nominally reduce emissions by dramatically increasing their proportion of emissions-heavy imports. ${ }^{153}$ This poor compliance record is despite the fact that the initial Kyoto targets were less than de minimis: even if all states had met their 2012 targets through genuine net emission reductions, these reductions would not have been sufficient to prevent dangerous anthropogenic interference with the climate system. ${ }^{154}$

Under the 2015 Paris Agreement, states agreed to the goal of keeping global average temperature rise 'well below $2^{\circ} \mathrm{C}$, while pursuing efforts to limit the increase to $1.5^{\circ} \mathrm{C}$ above pre-industrial levels' ${ }^{155}$ However, the Agreement relies on a pledge-and-review system of NDCs, and the first round of pledges were far too low to keep global warming to no more than 2 degrees Celsius, let alone no more than 1.5 degrees Celcius. ${ }^{156}$ Even if all of the pledges were met by the 2020 deadline, it would only account for roughly one third of the emission reductions needed to keep within the least ambitious and insufficient goal of 2 degrees Celcius of warming. ${ }^{157}$ The resulting temperature rise of an estimated 3.2 degrees Celcius by 2100 would be catastrophic for small island states like Vanuatu, as is clear from the protection challenges already apparent at current levels of warming. ${ }^{158}$ Here the greatest weakness of the international climate change regime becomes apparent: as NDCs are entirely voluntary and the Agreement lacks a strong compliance mechanism, it is difficult to hold states to

151 UNFCCC arts 3(1), 4(1). See also Lavanya Rajamani, 'The Reach and Limits of the Principle of Common but Differentiated Responsibilities and Respective Capabilities in the Climate Change Regime' in Navroz K Dubash (ed), Handbook of Climate Change and India: Development: Politics and Governance (Earthscan, 2012) 118.

152 Kyoto Protocol. See also Robert Henson, The Thinking Person's Guide to Climate Change (American Meteorological Society, 2014) 376-9.

153 This effect, called the 'displacement of emissions', is an ongoing problem for climate change action. Also note that at the same time, states that were not bound by the Kyoto Protocol also increased their emissions on average: Henson, above n 152, 376-9.

154 Ibid 379.

155 Paris Agreement art 2.

156 See Subsidiary Body for Scientific and Technological Advice and Subsidiary Body for Implementation, Report on the Structured Expert Dialogue on the 2013-2015 Review, 42 ${ }^{\text {nd }}$ sess, Agenda Items 6(b) and 12, UN Doc FCCC/SB/2015/INF.1 (4 May 2015); H O Pörtner, 'Climate Change: Ecosystem Impacts and Food Security' (Presentation at the Structured Expert Dialogue at COP 20, Lima, Peru, 2 December 2014) <http://unfccc.int/files/science/workstreams/systematic_observation/application/pdf/ipcc_li ma_poertner_12min.pdf $>$. See also Office of the United Nations High Commissioner for Human Rights, The Effects of Climate Change on the Full Enjoyment of Human Rights (Report provided by Special Procedures of the Human Rights Council to the Climate Vulnerable Forum, 30 April 2015) 3ff ('Effects of Climate Change Report').

157 United Nations Environment Programme, The Emissions Gap Report 2017: A UN Environment Synthesis Report (Report no DEW/2136/PA, United Nations Environment Programme, November 2017) xiv <https://www.unenvironment.org/resources/emissionsgap-report>.

158 See ibid xviii. See also Effects of Climate Change Report, above n 156; Pörtner, above n 156. 
account if their pledges are not in line with the long-term temperature goal, or if they fail to implement them. ${ }^{159}$

An integrated approach to human rights and climate change law can enhance accountability for mitigation actions that, ultimately, reduce some of the risks of climate displacement in states like Vanuatu. International human rights law not only provides obligations to protect peoples and individuals against forced displacement resulting from climate change that complement and reinforce obligations contained in international climate change law, but also has its own mechanisms of implementation that can be used to address climate change. 160 Conversely, obligations derived from international climate change law, as well as states' commitments reflected in NDCs, can be used as baselines in the assessment of states' compliance with their human rights obligations pertaining to climate change. The Mataso case study illustrates the importance of compliance with states' mitigation commitments contained in climate change law, as any further temperature rise will incrementally increase the risk of more devastating cyclones that exceed communities' coping capacities and interfere with the enjoyment of their human rights.

\section{B Climate Finance for Mitigation, Adaptation and Capacity Building}

Even if states were able to bring their climate laws, policies and practices in line with the Paris temperature goal, the quantity of greenhouse gases already in the atmosphere guarantees that we will continue to see an increase in global temperatures. ${ }^{161}$ This in turn makes it likely that the upward trend in the number of people displaced by climate-related disasters will continue into the future. ${ }^{162}$ However, much can be done to both prevent climate displacement and ensure the protection of the rights of displaced persons through sustainable development, adaptation and capacity building. The Internal Displacement Monitoring Centre ('IDMC') found that approximately 97 per cent of displacement between 200813 occurred in developing countries, indicating a strong correlation between poverty, exposure to hazards and displacement. ${ }^{163}$ In many developing nations, natural geographical vulnerability is amplified by low institutional capacity (including technical, financial and political capital). ${ }^{164}$ This is compounded yet further by social vulnerability associated with inequality, which can take the form of dense populations in informal settlements; lack of insurance and low savings rates; inadequate shelter; and precarious livelihoods or food

159 See also Margaretha Wewerinke-Singh and Curtis Doebbler, 'The Paris Agreement: Some Critical Reflections on Process and Substance' (2016) 39 University of New South Wales Law Journal 1486.

160 See also Margaretha Wewerinke, 'The Role of the UN Human Rights Council in Addressing Climate Change' (2014) 8 Human Rights and International Legal Discourse 10.

161 See IPCC AR4 2007, above n 32, 736.

162 Kälin, above n 1, 82.

163 Michelle Yonetani, 'Global Estimates 2014: People Displaced by Disasters' (Report, Internal Displacement Monitoring Centre and Norwegian Refugee Council, September 2014) 9.

164 Human Rights, Climate Change and Cross-Border Displacement, above n 3, 13. 
insecurity. ${ }^{165}$ These social and developmental factors can in turn undermine institutional capacity through low tax revenues, low rates of foreign direct investment and diversion of government funds to other sectors, creating a selfreinforcing cycle of underdevelopment. ${ }^{166}$ These data confirm that reducing social vulnerability in developing states is key to preventing climate displacement and enhancing the protection of the rights of climate displaced persons. ${ }^{167}$

The Mataso case study underscores the importance of ensuring that developing states like Vanuatu are equipped to deal with the unavoidable consequences of climate change that have already been 'locked in' by current emissions, including climate-related disasters that could result in involuntary displacement. It was noted in an earlier section that Vanuatu has adopted some of the most progressive climate change and displacement policies in the world. However, our discussions with community members, civil society and the government highlighted the challenges of protecting rights in practice. As long as Vanuatu lacks the resources and institutional capacity to operationalise its plans and guidelines, the protections and commitments made on paper will continue to have little impact on the experiences of communities like Mataso. Many of these plans were in place long before Cyclone Pam but could hardly be seen in action, if at all. Despite a number of reports and new policies based on the lessons learned in Pam, the recent difficulty in coordinating evacuations from the volcanic eruption in Ambae indicate that these policies have not progressed far from the desks of the NDMO in Port Vila. ${ }^{168}$

In interviews, officers from the NDMO expressed concern about their difficulty in implementing the new policies, noting the lack of adequate training and expertise among government staff in different sectors. ${ }^{169}$ They also noted that because of a lack of staffing, and because Vanuatu experiences earthquakes and volcanic eruptions on an almost daily basis, they are constantly preoccupied responding to current disasters and rarely have time to work on planning and implementing policies for future disasters. ${ }^{170}$ Vanuatu experiences an earthquake

165 See generally Robert R M Verchick, 'Disaster Justice: The Geography of Human Capability' (2012) 23 Duke Environmental Law \& Policy Forum 23; Office of the High Commissioner for Human Rights Regional Office for the Pacific, 'Protecting Human Rights of Internally Displaced Persons in Natural Disasters: Challenges in the Pacific' (Discussion Paper, 2011); Agenda for the Protection of Cross-Border Displaced Persons vol 1, 35 [76].

166 See Rosemary Lyster, 'A Fossil Fuel-Funded Climate Disaster Response Fund under the Warsaw International Mechanism for Loss and Damage Associated with Climate Change Impacts' (2015) 4 Transnational Environmental Law 125.

167 On social vulnerability, disasters and justice, see Verchick, above n 165, 66-7.

168 Interview with Interviewee 19, Senior officer at National Disaster Management Office, Port Vila (Port Vila, Shefa Province, Vanuatu, 25 July 2018); Interview with Interviewee 20, Policymaker at GIZ, Vanuatu (Port Vila, Shefa Province, Vanuatu, 20 July 2018); Interview with Interviewee 22, Vanuatu human rights advocate and civil society leader (Port Vila, Shefa Province, Vanuatu, 6 August 2018); Interview with Interviewee 23, Officer at International Organization for Migration, Vanuatu (Port Vila, Shefa Province, Vanuatu, 8 August 2018).

169 Interview with Interviewee 19, Senior officer at National Disaster Management Office, Port Vila (Port Vila, Shefa Province, Vanuatu, 25 July 2018).

170 Interview with Interviewee 19, Senior officer at National Disaster Management Office, Port Vila (Port Vila, Shefa Province, Vanuatu, 25 July 2018). 
of at least magnitude 4.0 every three days, on average, ${ }^{171}$ and the recent evacuations from Ambae, for example, come following three major volcanic eruptions which have preoccupied the NDMO since 2017.

During Cyclone Pam, a lack of institutional capacity combined with low development levels to increase the risk of displacement. Vanuatu's new National Climate Change and Displacement Policy reflects this relationship, noting that '[d]isplacement in Vanuatu needs to be understood within the broader mobility, climate change and development context of the country'. ${ }^{172}$ NDMO officials and humanitarian workers suggested that much of the displacement following Cyclone Pam could have been prevented with more investment in building adequate homes to withstand cyclones, and enforcing this through implementation of climate-smart land use planning and building codes. ${ }^{173}$ In many parts of Vanuatu, particularly the remote islands, community members can only access local materials to build homes, with the result that many dwellings cannot withstand cyclones. NDMO officials noted that with more funding for stronger materials and support to implement the building code, they could build stronger dwellings that would withstand cyclones, so that fewer people would be forced to relocate in search of emergency shelter following a severe cyclone. ${ }^{174}$ Both NDMO officials and civil society members also suggested that in remote areas lacking these resources, community outreach programs could at least help to ensure that community members have access to and are aware of a central community shelter that is built to withstand severe cyclones and other natural disasters, to reduce injuries and casualties during and immediately following disasters. ${ }^{175}$

In terms of compliance with human rights obligations, it is clear that Vanuatu can and must do more to prevent displacement and protect the rights of displaced persons. In addition to enhancing its efforts to implement existing policies, Vanuatu needs to provide assistance to community members such as those from Mataso who are seeking to migrate - either temporarily or permanently — in the face of a changing climate. As Jane McAdam and Marc Limon point out, '[w]hile displacement may be a sign of vulnerability, not moving may be a sign of even greater risk'. ${ }^{176}$ The IPCC has found that vulnerability is 'inversely

171 United States Geological Survey, Earthquake Track <https://www.earthquaketrack.com/p/vanuatu/recent?mag_filter=5>.

172 National Climate Change and Displacement Policy, above n 18, ix.

173 Interview with Interviewee 19, Senior officer at National Disaster Management Office, Port Vila (Port Vila, Shefa Province, Vanuatu, 25 July 2018); Interview with Interviewee 23, Officer at International Organization for Migration, Vanuatu (Port Vila, Shefa Province, Vanuatu, 8 August 2018).

174 Interview with Interviewee 19, Senior officer at National Disaster Management Office, Port Vila (Port Vila, Shefa Province, Vanuatu, 25 July 2018).

175 Interview with Interviewee 19, Senior officer at National Disaster Management Office, Port Vila (Port Vila, Shefa Province, Vanuatu, 25 July 2018); Interview with Interviewee 22, Vanuatu human rights advocate and civil society leader (Port Vila, Shefa Province, Vanuatu, 6 August 2018); Interview with Interviewee 23, Officer at International Organization for Migration, Vanuatu (Port Vila, Shefa Province, Vanuatu, 8 August 2018).

176 Human Rights, Climate Change and Cross-Border Displacement, above n 3, 15. See also Government Office for Science, 'Foresight: Migration and Global Environment Change' (Report, 2011). 
correlated with mobility', ${ }^{177}$ suggesting that migration should sometimes be seen as a positive adaptive step in the face of environmental and economic threats. ${ }^{178}$ Without adaptation programmes which also recognise this positive potential of migration in some cases, we risk entrenching a situation in which 'the most vulnerable people in a community (eg the elderly or the ill) may be unable to move at all, effectively becoming trapped'. ${ }^{179}$ In particular, adaptation and capacity building programmes need to recognise that individuals may have complex and dynamic reasons for either moving or staying put, and must empower those individuals to retain their autonomy and self-determination in making that choice.

At the same time, enhanced international support for adaptation and capacity building is needed to prevent human rights violations connected with climate displacement and other adverse effects of climate change experienced in Vanuatu. As these adverse effects worsen in future, still more resources will be needed to prevent and respond adequately to climate displacement. It is therefore important to recall that international human rights law imposes obligations of international cooperation on states to ensure that human rights are realised everywhere, as envisaged in the Charter of the United Nations and the Universal Declaration of Human Rights ('UDHR'). ${ }^{180}$ In parallel, international climate change law imposes specific obligations on developed states to provide assistance for climate mitigation and adaptation on the basis of equity and in accordance with the principle of common but differentiated responsibilities. ${ }^{181}$ The UNFCCC specifically requires developed states to provide new and

177 W Neil Adger et al, 'Human Security' in Intergovernmental Panel on Climate Change, Climate Change 2014 - Impacts, Adaptation, and Vulnerability. Part A: Global and Sectoral Aspects - Working Group II Contribution to the IPCC Fifth Assessment Report (Cambridge University Press, 2014) 755, 767.

178 See McAdam, Climate Change, Forced Migration, and International Law, above n 2, $201-$ 2; World Bank, World Development Report: Development and Climate Change (Report, World Bank, 2010); International Organization for Migration, 'Assessing the Evidence: Environment, Climate Change and Migration in Bangladesh' (Report, International Organization for Migration. 2010) 4, 6, 25, 35; Nansen Initiative, above n 165; Harriet Farquhar, "Migration with Dignity": Towards a New Zealand Response to Climate Change Displacement in the Pacific' (2015) 46 Victoria University of Wellington Law Review 29; Thomas and Benjamin, above $\mathrm{n} 147$.

179 Human Rights, Climate Change and Cross-Border Displacement, above n 3, 15. See also Richard Black and Michael Collyer, "Trapped" Populations: Limits on Mobility at Times of Crisis' in Susan F Martin, Sanjula Weerasinghe and Abbie Taylor (eds), Humanitarian Crises and Migration: Causes, Consequences and Responses (Routledge, 2014) 287; Carola Betzold, 'Adapting to Climate Change in Small Island Developing States' (2015) 133 Climatic Change 481, 287; W Neil Adger et al, above n 177, 767.

180 Universal Declaration of Human Rights, GA Res 217A (III), UN GAOR, $3^{\text {rd }}$ sess, $183^{\text {rd }}$ plen mtg, UN Doc A/810 (10 December 1948) ('UDHR'). These obligations are derived from arts 1, 55 and 56 of the Charter of the United Nations, customary international law and various international human rights treaties. On the effect of arts 55 and 56, see John $\mathrm{H}$ Knox, 'Climate Change and Human Rights Law' (2009) 50 Virginia Journal of International Law 163, 212; Office of the High Commissioner for Human Rights, Report of the Office of the United Nations High Commissioner for Human Rights on the Relationship between Climate Change and Human Rights, Agenda Item 2, UN Doc A/HRC/10/61 (15 January 2009); Margaretha Wewerinke-Singh, 'State Responsibility for Human Rights Violations Associated with Climate Change' in Sébastien Jodoin, Sébastien Duyck and Alyssa Johl (eds), Routledge Handbook on Human Rights and Climate Governance (Routledge, 2018) 21.

181 UNFCCC Preamble, arts 3(1), 4(1), 4(3), 4(4). See also Rajamani, above n 151. 
additional financial resources for climate action in developing states, and to assist developing states that are particularly vulnerable to the adverse effects of climate change in meeting costs of adaptation to those effects. ${ }^{182}$ As Walter Kälin and others have noted, '[s]ince the challenge of adaptation, properly understood, includes the need to adapt to the humanitarian consequences of climate change, adaptation measures must also cover protection of and assistance for the displaced'. ${ }^{183}$

The Paris Agreement reiterates that developed states shall provide financial resources to assist developing states with respect to both mitigation and adaptation in continuation of their existing obligations under the UNFCCC.184 While there is no agreement about the amounts to be provided, developed states pledged at the $15^{\text {th }}$ Conference of the Parties ('COP') in Copenhagen to mobilise US $\$ 100$ billion a year by 2020 to 'address the needs' of developing states; ${ }^{185}$ a pledge that was recognised in a COP decision at the $16^{\text {th }}$ COP in Cancun. ${ }^{186}$ In Paris, the COP decided that developed states would continue their existing collective mobilisation goal through 2025, and that prior to 2025 the COP serving as the meeting of the Parties to the Paris Agreement shall set a new collective quantified goal from a floor of US\$100 billion per year. ${ }^{187}$ Furthermore, the COP urged developed states to scale up their level of financial support, with a concrete roadmap to achieve the goal of jointly mobilising US $\$ 100$ billion a year by 2020 while significantly increasing adaptation finance from current levels. ${ }^{188}$

In 2016, states released a 'Roadmap' to US\$100 billion, claiming that they were on track to mobilise the funds by the 2020 deadline. ${ }^{189}$ However, the data sources underpinning this claim have been the subject of criticism, and the descriptions are sufficiently vague that it remains to be seen how states actually intend to raise the US $\$ 100$ billion. 190 The absence of modalities to account for climate finance continues to undermine the effectiveness of the climate change

182 UNFCCC art 4(3), (4).

183 Kälin, above n $1,83$.

184 Paris Agreement art 9(1).

185 See UNFCCC Conference of the Parties, Report of the Conference of the Parties on its Fifteenth Session, Held in Copenhagen from 7 to 19 December 2009: Addendum - Part 2: Action Taken by the Conference of the Parties at its Fifteenth Session, UN Doc FCCC/2/CP.15 (30 March 2010) 7 [8].

186 See UNFCCC Conference of the Parties, The Cancun Agreements: Outcome of the work of the Ad Hoc Working Group on Long-Term Cooperative Action under the Convention, UN Doc FCCC/CP/2010/7/Add.1 (15 March 2011) para 98.

187 See Report of the Conference of the Parties on its Twenty-First Session, Held in Paris from 30 November to 13 December 2015: Addendum - Part Two: Action Taken by the Conference of the Parties at its Twenty-First Session, UN Doc FCCC/CP/2015/10/Add.1 (29 January 2016) para 53 ('Adoption of the Paris Agreement').

188 See ibid para 114.

189 World Resources Institute, 'Statement: Developed Countries' Roadmap Shows Path to \$100 Billion Climate Finance Goal' on World Resources Institute (17 October 2016) <http://www.wri.org/news/2016/10/statement-developed-countries\%E2\%80\%99-roadmapshows-path-100-billion-climate-finance-goal $>$ archived at $\langle$ https://perma.cc/7SY6-RH7M $>$.

190 J Timmons Roberts and Romain Weikmans, 'Roadmap to Where? Is the " $\$ 100$ billion by 2020” Pledge from Copenhagen Still Realistic?' on Brookings Institution (20 October 2016) <https://www.brookings.edu/blog/planetpolicy/2016/10/20/roadmap-to-where-is-the-100billion-by-2020-pledge-from-copenhagen-still-realistic/> archived at $<$ https://perma.cc/HZ7E-QLUV>. 
regime when it comes to the provision of adaptation assistance to developing states such as Vanuatu; a problem amplified by the lack of a sanctioning mechanism for the non-fulfilment of pledges. ${ }^{191}$ Perhaps more importantly, research suggests that the US $\$ 100$ billion - even if it were to be provided as new and additional funds - would cover only a fraction of developing states' mitigation and adaptation needs. ${ }^{192}$ There is neither a plan to scale it up prior to 2025 nor a guarantee that the new collective quantified goal from a floor of US $\$ 100$ billion will be based on developing states' actual needs.

Again, an integrated approach to international law relating to climate displacement can enhance accountability for states' obligations relating to climate finance for adaptation. Developing states such as Vanuatu could report to human rights bodies on climate finance and other forms of assistance received from developed states, thus enhancing transparency and highlighting gaps. Moreover, human rights principles and standards could assist states like Vanuatu in identifying concrete adaptation, disaster risk reduction and capacity building needs, including in relation to climate displacement. If this is done in a bottomup, participatory manner, it would significantly bolster Vanuatu's capacity to claim that it is entitled to the requested assistance from developed states not only under the UNFCCC and the Paris Agreement, but also under international human rights law. At the same time, conducting a human rights needs assessment to inform requests for international assistance for adaptation and capacity building could enhance communities' awareness of their rights, while national stakeholders involved in the assessment are reminded of their obligations to respect, protect and fulfil those rights in the face of climate change.

Community participation in climate change adaptation and capacity building is also important to ensure that measures to respond to climate change complement local strategies for coping with disasters, such as those employed by ni-Vanuatu communities for generations in preparation for cyclones. Writing about flooding in Bangladesh, Jane McAdam observed that a long history of dealing with disasters has made local communities highly resilient and effective at managing disasters with tailored local coping strategies, much like those we heard about in Mataso, such as burying root vegetables to preserve them during disasters. ${ }^{193}$ To ensure that these local strategies are used in Vanuatu, local chiefs must be engaged as key partners throughout all stages of adaptation and capacity building programs, and local communities must be consulted at every step. ${ }^{194}$ At the same time, sensitivity to intersectional discrimination is needed to avoid

191 J Timmons Roberts and Romain Weikmans, 'Postface: Fragmentation, Failing Trust and Enduring Tensions Over What Counts as Climate Finance' (2017) 17 International Environmental Agreements: Politics, Law and Economics 129, 130.

192 Ian Callaghan, 'Climate Finance after COP21: Pathways to the Effective Financing of Commitments and Needs' (Report, InvestorWatch, December 2015) 10.

193 McAdam, Climate Change, Forced Migration, and International Law, above n 2, 174-5.

194 On the need to integrate local knowledge in climate change adaptation and displacement policies, see Ximena Flores-Palacious, 'Samoa: Local Knowledge, Climate Change and Population Movements’ (2015) 49 Forced Migration Review 59; Thomas and Benjamin, above $n 147$. 
inadvertently exacerbating pre-existing vulnerability and marginalisation in adaptation and capacity building activities. ${ }^{195}$

\section{Remedies and Compensation for Climate Displaced Persons}

While highlighting the need for climate change mitigation, adaptation and capacity, the Mataso case study also illustrates that climate change is already having adverse effects that occur despite mitigation and adaptation efforts. ${ }^{196}$ These adverse effects may already exceed communities' adaptive capacities. The experiences of the Mataso community call attention to the injustice that it is the poor and marginalised who are suffering most from these losses and damages. NDMO officials who we spoke with highlighted the widespread lack of insurance or savings by ni-Vanuatu people, which prevented many people from rebuilding after the cyclone hit, highlighting the strong connection between low incomes and disaster vulnerability. ${ }^{197}$ When we visited Mataso island in 2018, many people were still living in the tents provided by the United Nations Development Programme and the International Committee of the Red Cross after the cyclone. These people do not have any savings or disposable income with which to purchase materials to rebuild their homes, and with virtually all of the vegetation on the island uprooted during the cyclone, there are still not enough bush materials available to use. While a few of the tents have been fortified with sheets of corrugated iron apparently supplied by some school students from New Zealand, since returning to Mataso, the community has received no financial support from the government or international donors, and as such face no alternative but to continue living in the temporary tents.

In a state with no effective welfare system, the Mataso islanders are used to taking care of themselves without much assistance from the government. Many of the community members we spoke with noted the absence of any government presence or support in Mataso, both during the cyclone and in general. One man even said that the Vanuatu government 'doesn't recognise us'. ${ }^{198}$ When we asked the Mataso community members what kind of support they most need today, their answers reflected their history of self-reliance, all relating to measures that would enable them to return to their traditional livelihoods, and to better prepare themselves for the next disaster. One request was for the government to help establish a wholesale fishery station where wholesalers could purchase the catches of Mataso fishermen for retail sale in Port Vila. This would prevent them having to travel all the way to the city to sell at the market where they cannot compete with local fishermen due to their added travel costs. The community also asked for more funding for the local health clinic on the island, which is understaffed and underfunded. Community members currently have to

195 Office of the High Commissioner for Human Rights, 'OHCHR's Key Messages on Human Rights, Climate Change and Migration' on OHCHR Online <https://www.ohchr.org/Documents/Issues/ClimateChange/KeyMessages_on_HR_CC.pdf> archived at <https://perma.cc/NS39-MRB3>. See also Bhalla, above n 74; Verchick, above n 165.

196 IPCC AR4 2007, above n 32, 736.

197 Interview with Interviewee 19, Senior officer at National Disaster Management Office, Port Vila (Port Vila, Shefa Province, Vanuatu, 25 July 2018).

198 Interview with Interviewee 21, Mataso Island community member, male, living in Port Vila (Mataso, Shefa Province, Vanuatu, 7 May 2018). 
travel to Port Vila for most medical issues. As the journey takes two to three hours by boat, this can have serious consequences if bad weather delays travel, if they cannot afford the transport, or if anyone is too unwell for the boat journey. Both the islanders and members of civil society also noted the need for improved communications infrastructure in Mataso and other islands. ${ }^{199}$ Mobile service is unreliable and regularly goes down for extended periods. This issue was highlighted in the days before Cyclone Pam. Despite the NDMO tracking the cyclone for up to a week before it made landfall and issuing regular warnings through radio and local media outlets, some Mataso community members heard little or nothing of the cyclone until the day it hit, often then only through neighbours or family members living in Port Vila. ${ }^{200}$

All of these projects require funding. The increasing need for such funding was the main reason why SIDS - notably led by Vanuatu - started advocating for an insurance mechanism to address loss and damage resulting from climate change at the time the UNFCCC was negotiated. ${ }^{201}$ This advocacy ultimately culminated in the establishment of the Warsaw International Mechanism for Loss and Damage Associated with Climate Change Impacts ('Warsaw Mechanism') 202 under the 2013 Cancun Adaptation Framework. ${ }^{203}$ The Warsaw Mechanism is intended to address the effects of climate change in 'the most vulnerable developing countries, who are recognised as bearing disproportionate costs from climate change, having both contributed the least to the problem and the least capacity to manage its negative impacts'.204 The Paris Agreement permanently anchored the Warsaw Mechanism into the international climate change regime through its art 8 , which has been called an 'ambitious

199 Interview with Interviewee 15, Mataso Island community member, mother (Mataso, Shefa Province, Vanuatu, 7 May 2018); Interview with Interviewee 17, Mataso Island community member, female, youth (Mataso, Shefa Province, Vanuatu, 7 May 2018); Interview with Interviewee 22, Vanuatu human rights advocate and civil society leader (Port Vila, Shefa Province, Vanuatu, 6 August 2018); Interview with Interviewee 23, Officer at International Organization for Migration, Vanuatu (Port Vila, Shefa Province, Vanuatu, 8 August 2018).

200 Interview with Interviewee 15, Mataso Island community member, mother (Mataso, Shefa Province, Vanuatu, 7 May 2018); Interview with Interviewee 17, Mataso Island community member, female, youth (Mataso, Shefa Province, Vanuatu, 7 May 2018).

201 See John W Ashe, Robert Van Lierop and Anilla Cherian, 'The Role of the Alliance of Small Island States (AOSIS) in the Negotiation of the United Nations Framework Convention on Climate Change (UNFCCC)' (1999) 23 Natural Resources Forum 209.

202 Warsaw International Mechanism for Loss and Damage Associated with Climate Change Impacts, $19^{\text {th }}$ sess, Agenda Item 3(b), UN Doc FCCC/CP/2013/L.15 (22 November 2013).

203 Subsidiary Body for Scientific and Technological Advice and Subsidiary Body for Implementation, Report of the Executive Committee of the Warsaw International Mechanism for Loss and Damage Associated with Climate Change Impacts, UN Doc FCCC/SB/2014/4, (24 October 2014) annex II.

204 Climate Focus, 'Loss and Damage in the Paris Agreement: Climate Focus Client Brief on the Paris Agreement IV' (Briefing Note, February 2016) 1, $<$ https://climatefocus.com/sites/default/files/20160214\%20Loss\%20and\%20Damage\%20Par is_FIN.pdf> archived at <https://perma.cc/54KR-AJV7> ('Loss and Damage in the Paris Agreement'). See generally Kirstin Dow et al, 'Commentary: Limits to Adaptation' (2013) 3 Nature Climate Change 305; Koko Warner, Kees van der Geest and Sönke Kreft, 'Pushed to the Limit: Evidence of Climate Change-Related Loss and Damage when People Face Constraints and Limits to Adaptation' (Report No 11, United Nations University Institute for Environment and Human Security, November 2013) $\langle$ https://collections.unu.edu/eserv/UNU:1849/pdf11486.pdf> archived at $<$ https://perma.cc/LJ55-UTZS $>$. 
compromise' 205 on loss and damage. Moreover, at the $21^{\text {st }}$ COP in Paris, states resolved to establish a Taskforce on Displacement under the Warsaw Mechanism, which is set to provide recommendations for 'integrated approaches to avert, minimise and address displacement related to the adverse impacts of climate change' to the $24^{\text {th }}$ COP later this year. ${ }^{206}$ However, the Paris Agreement stopped short of integrating the right to a remedy for victims of climate change. ${ }^{207}$ The language of the text carefully avoids any suggestion of legal or financial liability - the major concern of developed states who have resisted development of the Warsaw Mechanism - and clarifies that obligations are facilitative and cooperative only. ${ }^{208}$ Indeed, the COP decision to which the Paris Agreement was annexed specifically stated that the Paris provision on loss and damage 'does not involve or provide a basis for any liability or compensation'. ${ }^{209}$ No new funding streams for loss and damage have been created, and the Green Climate Fund has not been mandated to distribute finance for loss and damage. In short, the Warsaw Mechanism is still not fully operational, despite clear and accumulating loss and damage due to anthropogenic climate change, of the sort that Vanuatu and other developing states believe it should compensate. ${ }^{210}$ The resistance of developed states to the incorporation of any kind of legal or financial liability for climate change in a mechanism for loss and damage rests on their awareness that if such a mechanism were operational, many of them might indeed be liable, because there is increasingly solid evidence to demonstrate that the contribution of

205 Laurent Fabius, 'Déclaration de M Laurent Fabius, Ministre des affaires étrangères et du développement international, sur la preparation de la Conférence de Paris sur le climat, à Paris le 8 novembre 2015' [Declaration by Mr Laurent Fabius, Minister of Foreign Affairs and International Development, on the Preparation of the Paris Climate Conference, in Paris on 8 November 2015] (Speech delivered at the opening of the pre-COP meeting, 8 November 2015); Paris Agreement art 8.

206 Adoption of the Paris Agreement, UN Doc FCCC/CP/2015/10/Add.1, 8.

207 Paris Agreement art 8. See also Republic of Nauru, 'Submission of Nauru on Behalf of the Alliance of Small Island States: Views and Information on Elements to Be Included in the Recommendations on Loss and Damage in Accordance with Decision 1/CP.16', Submission to the UNFCCC, 28 September 2012, 4 <http://aosis.org/wpcontent/uploads/2012/11/AOSIS-Submission-on-Loss-and-Damage-Submission-Final.pdf > <https://perma.cc/EV3N-QFPR>; Republic of The Gambia, 'Submission of the Gambia on Behalf of the Least Developed Countries Group on Loss and Damage', Submission to the $\begin{array}{lllll}\text { UNFCCC, } & \text { October } & 2012, & 8, & 12-13\end{array}$ $<$ https://unfccc.int/files/adaptation/application/pdf/submission_by_the_gambia_on_behalf_o f_the_least_developed_countries_on_loss_and_damage.pdf $>\quad-\quad$ archived - at <https://perma.cc/87BA-PKUN>. See also Kathleen Mogelgaard and Heather McGray, 'When Adaptation Is Not Enough: Paris Agreement Recognizes "Loss and Damage" on World Resources Institute (24 December 2015) <http://www.wri.org/blog/2015/12/whenadaptation-not-enough-paris-agreement-recognizes-\%E2\%80\%9Closs-anddamage\%E2\%80\%9D> archived at <https://perma.cc/Y2NJ-RHLC>; Loss and Damage in the Paris Agreement, above n 204, 3-4.

208 Paris Agreement art 8; Adoption of the Paris Agreement, UN Doc FCCC/CP/2015/10/Add.1, paras 49-51.

209 Ibid para 52.

210 See Republic of Vanuatu, 'Submission to the Executive Committee of the Warsaw International Mechanism for Loss and Damage Associated with Climate Change Impacts', Submission to the Executive Committee of the Warsaw International Mechanism for Loss and Damage Associated with Climate Change Impacts (29 January 2018) <http://unfccc.int/files/adaptation/workstreams/loss_and_damage/application/pdf/vanuatu_s ubmission.pdf $>$ archived at $\langle$ https://perma.cc/5ZFF-QZHL $>$. 
historical greenhouse gas emissions from industrialised nations has contributed substantially to loss and damage in developing states. ${ }^{211}$

In theory, the Warsaw Mechanism could be an important vehicle for preventing and addressing human rights harms relating to climate change and displacement. The Office of the United Nations High Commissioner for Human Rights has affirmed that '[s]tates are required to provide effective mechanisms to prevent and redress human rights harms resulting from the adverse effects of climate change' in relation to displaced persons, in accordance with the right to a remedy guaranteed in the $U D H R$ and ICCPR. ${ }^{212}$ Moreover, it has underscored that '[s]tates must be accountable for their contribution to human rights harms regardless of where they occur' and that accountability must also include businesses and private actors that have contributed to climate change. ${ }^{213}$ Along with several international NGOs, Rosemary Lyster has proposed that the Warsaw Mechanism should be funded through a levy on the world's largest 200 fossil fuel companies, in a model inspired by precedents like compensation funds established for damage caused by oil spills, asbestos and nuclear accidents. ${ }^{214}$ The rationale here is that ultimately, both the developed states and private entities are responsible for the harmful effects of anthropogenic climate change - and both have been able to so far avoid any meaningful responsibility for these long-known effects. Developed states should engage with this responsibility by incorporating clear obligations for the provision of funding to be channelled to the victims of loss and damage from climate change.

The Mataso case study also serves as an illustration that addressing the human rights implications of loss and damage resulting from climate change must go beyond financial compensation. The Mataso islanders we spoke to overwhelmingly expressed their love of their home island, and their connection to the land and the ocean there. One man told us that he saw the land and sea as both friends and enemies, and that both were at the centre of his identity in Mataso. ${ }^{215}$ Several respondents insisted that despite struggling at times to secure enough food and income, they could not bear to live anywhere else because

211 On differentiated contributions to climate change and related loss and damage see IPCC AR5 2014, above n 8; IPCC AR4 2007, above n 32, 359.

212 Ibid; UDHR.

213 OHCHR 2018 Report, UN Doc A/HRC/38/21, 12 [48].

214 Lyster, above n 166. See also Julie-Anne Richards and Liane Schalatek, 'Financing Loss and Damage: A Look at Governance and Implementation Options' (Discussion Paper, Heinrich Boll Stiftung North America, May 2017) 20-1 <https://us.boell.org/sites/default/files/uploads/2017/05/loss_and_damage_finance_paper_u pdate_16_may_2017.pdf> archived at <https://perma.cc/23N7-WKUU>.

215 Interview with Interviewee 1, Mataso Island community member, father (Mataso, Shefa Province, Vanuatu, 7 May 2018). 
Mataso is their only home. ${ }^{216}$ Since Pam, however, many described the environmental situation as 'beyond their capacity' to manage, and lamented that they could no longer survive there the way they had for generations. ${ }^{217}$ For these islanders, there is no form of compensation or adaptation which can fully remedy the loss of their homeland as it was known to them. This position is common throughout the world - people are obligingly bound to their homelands through an intimate connection to the land and sea, which is bolstered by important socio-economic factors such as proximity to family, local knowledge of resources, the majority or entirety of one's assets consisting of the land they have improved and cultivated, and a distinct sense of 'home'. ${ }^{218}$ A holistic consideration of the factors underpinning decisions to move from Mataso to Port Vila makes it clear that it would be an inaccurate simplification to categorise this movement as a form of adaptation, without recognising the losses and damages that factored into the decision to move and the additional losses and damages resulting from actually leaving one's homeland behind. More work is needed at the grassroots level as well as internationally to deal with these non-economic losses, and participatory approaches are needed to ensure that those who have suffered human rights violations as a result of climate impacts and associated displacement get access to remedies that restore the enjoyment of their rights to the greatest extent possible.

\section{CONCLUSION}

The Government of Vanuatu is chiefly responsible for protecting the human rights of its citizens, including in the face of a changing climate. However, as noted above, its ability to prevent displacement and protect human rights during climate-related disasters is undermined by a lack of resources and institutional capacity. The experiences of the Mataso community members make clear the need for a more comprehensive human rights-based approach to climate change,

216 Interview with Interviewee 1, Mataso Island community member, father (Mataso, Shefa Province, Vanuatu, 7 May 2018); Interview with Interviewee 2, Mataso Island community member, mother (Mataso, Shefa Province, Vanuatu, 7 May 2018); Interview with Interviewee 3, Mataso Island community member, father (Mataso, Shefa Province, Vanuatu, 7 May 2018); Interview with Interviewee 4, Mataso Island community member, male (Mataso, Shefa Province, Vanuatu, 7 May 2018); Interview with Interviewee 6, Mataso Island community member, father, (Mataso, Shefa Province, Vanuatu, 7 May 2018); Interview with Interviewee 8, Mataso Island community elder, male, worked in Port Vila (Mataso, Shefa Province, Vanuatu, 7 May 2018); Interview with Interviewee 9, Mataso Island community member, father (Mataso, Shefa Province, Vanuatu, 7 May 2018); Interview with Interviewee 10, Mataso Island community member, mother (Mataso, Shefa Province, Vanuatu, 7 May 2018); Interview with Interviewee 11, Mataso Island community member, male, youth (Mataso, Shefa Province, Vanuatu, 7 May 2018); Interview with Interviewee 12, Mataso Island community member, male, youth (Mataso, Shefa Province, Vanuatu, 7 May 2018); Interview with Interviewee 14, Mataso Island community elder, male (Mataso, Shefa Province, Vanuatu, 7 May 2018); Interview with Interviewee 15, Mataso Island community member, mother (Mataso, Shefa Province, Vanuatu, 7 May 2018); Interview with Interviewee 16, Mataso Island community elder, female (Mataso, Shefa Province, Vanuatu, 7 May 2018).

217 Interview with Interviewee 6, Mataso Island community member, father, (Mataso, Shefa Province, Vanuatu, 7 May 2018); Interview with Interviewee 7, Mataso Island community member, father (Mataso, Shefa Province, Vanuatu, 7 May 2018).

218 Regarding indigenous groups, see OHCHR 2018 Report, UN doc A/HRC/38/21, 6 [19]; Interview with Interviewee 23, Officer at International Organization for Migration, Vanuatu (Port Vila, Shefa Province, Vanuatu, 8 August 2018). 
displacement, and disaster preparedness, response and recovery that builds on collaboration between donors, international organisations, NGOs and other stakeholders. Communities must be engaged at all levels of planning and response, and should also be involved in climate change mitigation, adaptation and capacity building projects. The new National Climate Change and Displacement Policy will bring welcome progress on all these points - if it can be successfully implemented. Therein lies an important potential contribution of a more integrated approach to international law in connection with climate displacement, including enhanced accountability for compliance with existing obligations relating to climate change mitigation, adaptation, capacity building and loss and damage. Together, human rights law and climate change law provide important - and legally binding — pointers on the actions that need to be taken to meet these obligations. If developed states continue to fail to meet their obligations to reduce emissions and to provide sufficient funds for climate mitigation, adaptation and capacity building to developing states like Vanuatu, more islanders from Mataso, along with people from all over Vanuatu and the rest of the developing and small island states, will be forced to uproot their families and walk away from generations and centuries of history and culture, as their homelands become uninhabitable. Vanuatu's experience with Cyclone Pam also provides a clear case for strengthening the Warsaw Mechanism in order to facilitate the provision of financial assistance to states already suffering from adverse effects of climate change that occur despite mitigation and adaptation efforts.

At the same time, some of the most pressing questions relating to the interpretation and implementation of international obligations relating to climate displacement remain unanswered. Interdisciplinary research, input from affected states and communities and further international deliberations are needed to address questions such as: how can the principle of CBDRRC be operationalised to advance the rights of climate displaced persons in developing states? What levels of financial support for preventing and addressing climate displacement in developing states must developed states provide to comply with their 'extraterritorial' human rights obligations? ${ }^{219}$ What does the right to an adequate and effective remedy entail in situations where people are forced to leave their homeland as a direct or indirect result of climate change, and how can responsibility for providing such remedies be apportioned between states in this context? While some of these questions have been touched upon by the Warsaw Mechanism and its Task Force on Displacement, no concrete answers have been provided. The international human rights community has a particularly important role to play in providing guidance that can help states to bring the work of the Warsaw Mechanism, other international mechanisms as well as their own practice and policies in line with human rights norms calling for enhanced protection of climate displaced persons.

219 For an analogous discussion, see Wouter Vandenhole, 'Economic, Social and Cultural Rights in the CRC: Is There a Legal Obligation to Cooperate Internationally for Development?' (2009) 17 The International Journal of Children's Rights 23: suggesting that developed states have a specific human rights obligation to allocate 0.7 per cent of GDP to development assistance. 